CHEMICAL QUALITY OF THE SAW MILL RIVER, WESTCHESTER COUNTY, NEW YORK, 1981-83

By Robert J. Rogers

U.S. GEOLOGICAL SURVEY

Water-Resources Investigations Report $84-4225$

Prepared in cooperation with the

WESTCHESTER COUNTY DEPARTMENT OF HEALTH

Al bany, New York

1984 


\section{UNITED STATES DEPARTMENT OF THE INTERIOR \\ WILLIAM P. CLARK, Secretary}

GEOLOGICAL SURVEY

Dallas L. Peck, Director

For additional information write to:

Copies of this report may be purchased from:

U.S. Geological Survey

P.0. Box 1669

Al bany, New York 12201

(518) 472-3107

Open-File Services Section Western Distribution $\mathrm{Br}$ anch

U.S. Geological Survey

Box 25425, Denver Federal Center

Denver, Colo. 80225

(303) 234-5888 
Abstract . . . . . . . . . . . . . . . . . . . . 1

Introduction . . . . . . . . . . . . . . . . . . . . 2

Purpose and scope........................ . 4

Acknowledgments . . . . . . . . . . . . . . . . . 4

Basin description. . . . . . . . . . . . . . . . . . . . 4

Physiography and geology. . . . . . . . . . . . . . . 4

Climate.......................... . 5

Streamflow. . . . . . . . . . . . . . . . . . . 5

River quality... . . . . . . . . . . . . . . 6

Land use. . . . . . . . . . . . . . . . . . . 7

Data collection. . . . . . . . . . . . . . . . . . . . 7

Sampling media and sample collection. . . . . . . . . . . . 7

Bottom sediments . . . . . . . . . . . . . . 7

River water. . . . . . . . . . . . . . . 10

Soils......................... 10

Ceramic tiles....................... 11

Sample preparation and analyses . . . . . . . . . . . . . . 11

Sample preparation . . . . . . . . . . . . . 11

Chemical analyses. . . . . . . . . . . . . . 12

Grain-size analyses. . . . . . . . . . . . . . 13

Chemical quality of Saw Mill River . . . . . . . . . . . . . 15

Nutrients . . . . . . . . . . . . . . . . . . . 15

River water. . . . . . . . . . . . . . . . 15

Bottom sediments................... 15

Heavy metals. . . . . . . . . . . . . . . . 16

River water. . . . . . . . . . . . . . . . 16

Bot tom sedinents................... 16

Soils......................... 23

Ceramic tiles.................... 25

Organic compounds . . . . . . . . . . . . . . . . 28

River water. . . . . . . . . . . . . . 28

Bottom sediments.................... 29

Relation of river quality to urbanization. . . . . . . . . . . 35

Summary. . . . . . . . . . . . . . . . . . . . . . 37

References . . . . . . . . . . . . . . . . . . 40

\section{ILLUSTRATIONS}

Figure 1.--Map showing location of sampling sites in the Saw Mill River basin.................... 3

2.--Elevation profile of the Saw Mill River.......... 4

3.--Hydrograph showing monthly streamflow of the Saw Mil1

River at Yonkers. . . . . . . . . . . . . . . . . 


\section{ILLUSTRATIONS (continued)}

Page

Figure 4.--Graph showing relation of heavy-metal concentration to sediment grain size at site 320 , near upper end of basin, and site 503, near lower end of basin .........

5.--P lots showing heavy-metal concentrations in 1,000- to $2,000-\mu \mathrm{m}$ bottom sediment in the Saw Mill River

A. Copper, lead, and zinc. B. Iron and manganese .....

6.--Graph showing concentrations of heavy metals deposited on ceramic tiles emplaced in the Saw Mill River.......

7.--Plots showing chlorinated hydrocarbon concentrations in bottom sediments in the Saw Mill River. A. Dieldrin and DDD + DDE + DDT. B. Chlordane and PCB....

\section{TABLES}

Table 1.--Location of the 20 sampling sites on the Saw Mill

River and tributaries . . . . . . . . . . . .

2.--Acid- and base/neutral-extractable organic compounds for which water and bottom-sediment samples were analyzed ... .

3.--Principal volatile organic compounds for which water samples were analyzed ...............

4.--Organochlorine and organophosphorous compounds for which water and bottom-sediment samples were analyzed . . . . 14

5.--Heavy-metal concentrations is size fraction of bottom sediments from the Saw Mill River, 1981 . . . . . . 17

6.--Dry-we ight percentage of sediment size fractions in riverbottom sediments from Saw Mill River and tributaries, 1981. • 19

7.--Heavy-metal concentrations in 1,000- to 2,000- $\mu \mathrm{m}$ bottom sediment from the Saw Mill River and tributaries, 1981-82 • 2 20

8.--Correlation coefficients of heavy metals in upstream and downstream bottom sediments from the Saw Mil1 River and tributaries, 1981-82.............. 23

9.--He avy-metal concentrations in soils from the Saw Mill River basin, 1981 . . . . . . . . . . . . . 24

10.--Heavy-meta 1 concentrations on ceramic tiles emplaced on bottom of the Saw Mill River . . . . . . . . 26 
Table 11.--Concentrations of volatile organic compounds in the Saw Mill River, 1981-82................ 28

12.--Concentrations of organochlorine compounds in bottom sediments from the Saw Mil1 River, 1981 . . . . . . . 30

13.--Concentrations of organochlorine compounds in bottom sediments from the Saw Mil1 River, 1976 .......... 31

14.--Concentrations of acid- and base/neutral-extractable compounds in bottom sediments from the Saw Mil1 River, 1981-82 . 32

15.--Uses of selected heavy metals .............. 36

16.--Concentrations of nitrogen, phosphorus, and carbon in water from the Saw Mill River, 1981-82. . . . . . . . 44

17.--Concentrations of nitrogen, phosphorus, and carbon in bottom sediments from the Saw Mi11 River, 1981-82 . . . . 46

18.--Concentrations of heavy metals in waters from the Saw Mill River, 1981-82. . . . . . . . . . . . . . 50

\section{CONVERSION FACTORS AND ABBREVIATIONS}

The following factors may be used to coivert the inch-pound units used herein to the International System of Units (SI).

$\begin{array}{lll}\text { Multiply inch-pound unit } & \text { By } & \text { To obtain SI (metric) unit } \\ \text { inch (in.) } & 2.54 & \text { centimeter }(\mathrm{cm}) \\ \text { foot (ft) } & 30.48 & \text { centimeter }(\mathrm{cm}) \\ \text { mile (mi) } & 1.609 & \text { kilometer }(\mathrm{km}) \\ \text { square mile }\left(\mathrm{mi}^{2}\right) & 2.590 & \text { square kilometer }\left(\mathrm{km}^{2}\right) \\ \text { cubic foot per second }\left(\mathrm{ft}^{3} / \mathrm{s}\right) & 0.02832 & \text { cubic meter per second }\left(\mathrm{m}^{3} / \mathrm{s}\right) \\ \text { gallons (gal) } & 0.003785 & \text { cubic meter }\left(\mathrm{m}^{3}\right) \\ \text { million gallons per day (Mgal/d) } & 0.04381 & \text { cubic meters per second }\left(\mathrm{m}^{3} / \mathrm{s}\right) \\ \text { degrees Fahrenheit }\left({ }^{\circ} \mathrm{F}\right) & 1.8 \times{ }^{\circ} \mathrm{C}+32 & \text { degrees Celsius }\left({ }^{\circ} \mathrm{C}\right)\end{array}$

\section{Other Abbrevlations}

micrometers $(\mu \mathrm{m})$

milligrams per liter (mg/1)

micrograms per liter $(\mu \mathrm{g} / 1)$

micrograms per gram (ing/g) ml 11 ligrams per kilograms (mg/kg)

mi crograms per kilogram ( $\mu \mathrm{g} / \mathrm{kg})$

nanograms por sqare centimeter $\left(\mathrm{ng} / \mathrm{cm}^{2}\right)$ 


\title{
CHEMICAL QUALITY OF THE SAW MILL RIVER, WESTCHESTER COUNTY, NEW YORK, 1981-83
}

\author{
By Robert J. Rogers
}

\section{ABSTRACT}

Concentration and distribution of contaminants in the Saw Mil1 River, which drains a heavily developed basin adjacent to New York City, was studied during 1981-83. River water and bottom sediments were analyzed for nutrients, heavy metals, and synthetic organic compounds. Coatings that formed on submerged ceramic tiles emplaced in the river for the study were analyzed for heavy metals. Soils near the river were also analyzed for heavy metals.

Bottom-sediment chemistry was the main focus of the study. Bottom sediments from six sites were separated into six size fractions to determine the relationship between grain size and concentrations of heavy metals and nutrients. The spatial distribution of heavy metals in bottom sediments was investigated by using 1,000- to 2,000-micrometer ( $\mu \mathrm{m})$ sediment; the distribution of organic compounds was investigated by using sediment composed of all particles less than $2,000 \mu \mathrm{m}$.

Among the nutrients studied, nitrite, nitrate, and un-ionized ammonia concentrations did not exceed U.S. Environmental Protection Agency (USEPA) water-quality criteria. The highest concentrations of dissolved orthophosphate ( 0.04 to $0.10 \mathrm{milligrams}$ per 1 iter) were observed in the 1 ower 8 miles of the river. Nitrogen, phosphorus, and organic carbon concentrations were typically higher in 1,000-to 2,000- $\mu \mathrm{m}$ bottom sediments than in 250- to 1,000- $\mathrm{mm}$ sediment and were highest in the fraction less than $250 \mu \mathrm{m}$.

The only heavy metal to regularly exceed USEPA criteria was dissolved manganese. The highest concentrations of arsenic, cadmium, copper, lead, and zinc were in water from the lower 4 river miles. In bottom sediments, heavymetals concentrations were higher in $1,000-$ to $2,000-\mu \mathrm{m}$ sediment than in 500-to 1,000- $\mu \mathrm{m}$ sediment and highest in the fraction less than $250 \mu \mathrm{m}$. Sediments in the 1,000- to 2,000- $\mu \mathrm{m}$ fraction from the lower 3 river miles contained significantly greater amounts of copper, lead, and zinc than sediments upstream, and concentrations of these metals were also highest in riverbank soils below river mile 3.0. The most abundant metal deposited on the ceramic tiles was manganese. Concentrations of all metals investigated--cadmium, cobalt, copper, iron, lead, manganese, nickel, and zinc--were highest on tiles from below river mile 3.0 .

Few organic compounds were detected in the river water. Four volatile organic compounds were detected at concentrations of 2 to 30 micrograms per liter $(\mu \mathrm{g} / \mathrm{L})$. Samples from three of 11 sites contained total phenol concentrations of 1 to $4 \mu \mathrm{g} / \mathrm{L}$; the rest were below detection limit. Polychlorinated biphenyls (PCB's) were detected in one water sample at a concentration of 0.1 $\mu \mathrm{g} / \mathrm{L}$. Chlordane, DDD, DDE, DDT, dieldrin, and PCB were found in bottom sediments throughout the basin. The six highest $\mathrm{PCB}$ concentrations (58 to 2,100 micrograms per kilogram) were found in the lower 6 river miles. Chlordane was the most abundant pesticide in the bottom sediments. None of the pesticides 
exhibited a spatial pattern. Of the 57 acid- and base/neutral-extractable compounds on the USEPA "priority pollutant" 1 ist, 22 were detected in bottom sediments; 16 were polynuclear aromatic hydrocarbons; and 4 were phthalate esters. None of the 22 compounds was found at all sites sampled. The greatest number of organic compounds was found below river mile 2.0. Cyanide was not detected in any water or bottom-sediment sample.

The area below river mile 3.7 is the most heavily urbanized part of the basin. Concentrations of orthophosphate, heavy metals, PCB's, and polynuclear aromatic hydrocarbons increase downstream and are highest in the urbanized reach below river mile 3.7. Urban runoff, rather than recorded point sources of contaminants, is considered the major cause of the downstream deterioration in river quality.

\section{INTRODUCTION}

The chemical quality of rivers is affected by virtually all types of development. Many compounds entering a river as a consequence of urban deve1opment do so from point sources and from general runoff. Potential contaminants include plant nutrients, heavy metals, and synthetic organic compounds such as pesticides. Contaminants commonly enter a river at low, subtoxic concentrations but may accumulate in the bottom sediments. If the contaminants reach critical concentrations within the sediment, they prove toxic to aquatic life and, if redissolved or suspended, may render a river unfit for use as a water supply. Thus, assessments of river quality must consider not only the quality of the water but also of the bottom sediments.

Many residents of Westchester County in southwestern New York (fig. 1) rely on the Saw Mill River drainage for part of their water supply. The lower section of the river flows through the City of Yonkers, a heavily urbanized section of the county. Results of a 1976 study by the U.S. Geological Survey (Archer and Turk, 1977) suggest that bottom sediments in the downstream (southern) section of the river are enriched in metals and organochlorine compounds.

Discharge of wastewater into the Saw Mill River is stringently controlled. No municipal waste and few recorded industrial wastes are discharged to the river. However, county officials have for many years received reports of illegal and accidental discharges into the river, especially along the lower reaches, and untreated domestic sewage occasionally enters the river as a consequence of broken pipes or other malfunctions. The Westchester County Department of Health routinely investigates all reports of spills and discharges.

The City of Yonkers maintains a water-treatment plant at about river mile 3.2 to meet part of its water needs. The plant has been closed at times because of turbid water or low-flow conditions, and in August 1982 the plant was closed because of objectionable taste and odor and remained closed as of September 1984. Other water users include the Village of Tarrytown in the Town of Greenburgh, which maintains a reservoir on a tributary (fig. 1), and several industries that use the river as a source of cooling water. 


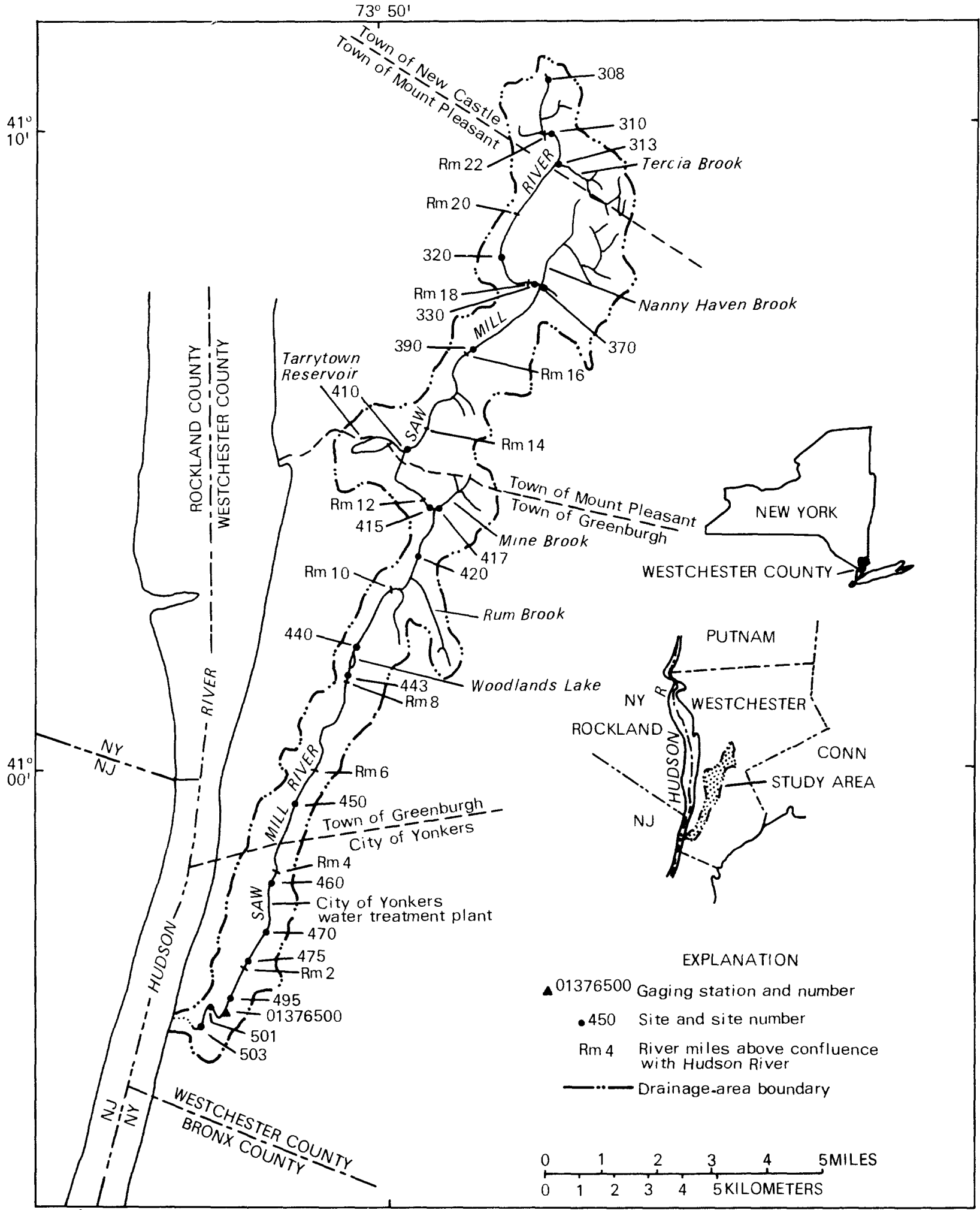

Base from U.S. Geological Survey

State base map, 1:500,000, 1974

Figure 1.--Location of sampling sites in the Saw Mill River basin. 


\section{Purpose and Scope}

In October 1980, the U.S. Geological Survey, in cooperation with the Westchester County Department of Health, began a 3-year study of the chemical quality of the Saw Mill River. This report, which presents the results of that study, (1) identifies contaminants in the river and provides information on their concentration, and (2) describes the distribution of contaminants and relates the distribution to land use, urbanization, and possible sources.

The sampling program, which extended from February 1981 through February 1983, covered the entire river and several tributaries. Emphasis was placed on the quality of river-bottom sediments, which strongly sorb many contaminants from the water column. Bottom sediments were sampled at 20 sites; water samples were collected at 11 of the sites. Water and bottom-sediment samples were analyzed for heavy metals (density $>6 \mathrm{~g} / \mathrm{cm}^{3}$ ), major nutrients, U.S. Environmental Protection Agency (USEPA) "priority pollutants" (Keith and Telliard, 1979), and other synthetic organic compounds, such as pesticides. Soil samples from 10 sites in the river's drainage basin were analyzed to aid in interpreting the heavy-metal chemistry of the bottom sediments.

\section{Acknowledoments}

The Westchester County Department of Health provided technical support and partial funding for this study.

\section{DASIN DESCRIPTION}

\section{Physlography and Goology}

The Saw Mill River rises in the Town of New Castle (fig. 1) at an altitude of $500 \mathrm{ft}$. It flows southward, passes through the City of Yonkers, and empties into the Hudson River at sea level. A streambed profile is shown in figure 2. The last 0.4 miles of the river passes through a covered concrete conduit. The river is $23.5 \mathrm{mi}$ long and drains a narrow basin that is 26.5 $\mathrm{mi}^{2}$ in area and surrounded by hills, some with steep slopes. It has few tributaries; a 11 are less than $2.0 \mathrm{mi}$ 1ong. The Saw Mill River basin lies in the Manhattan Hills in the New England Upland physiographic province (Cressey, 1966). It is entirely within westchester County and drains part or all of 12 municipalities.

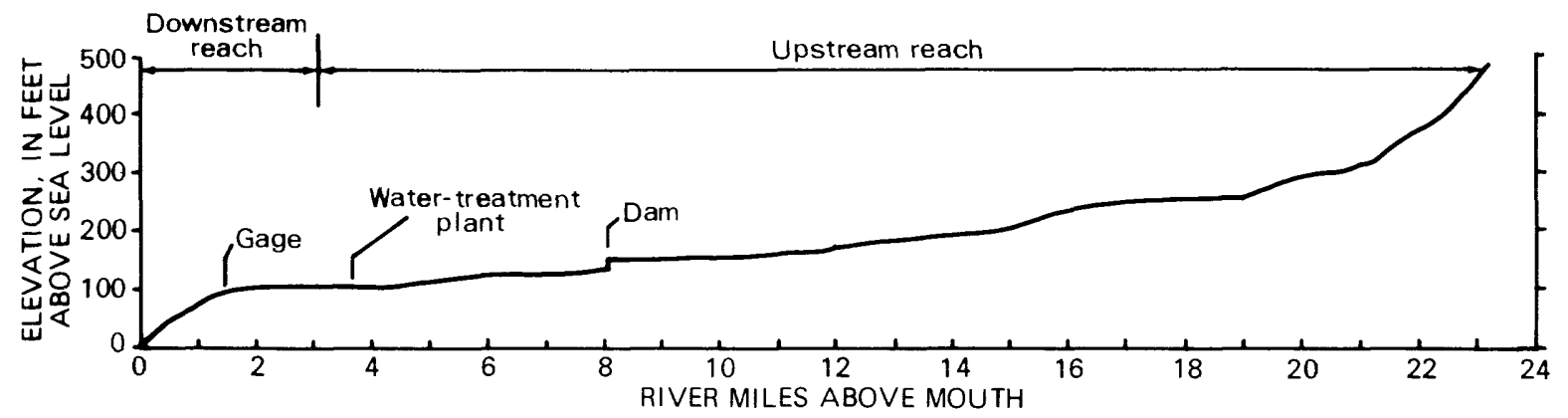

Figure 2.--Elevation profile of the Saw Mill River. 
The basin i-s underlain by metamorphic rocks, primarily gneiss, schist, and marble (Fisher and others, 1970). Bedrock outcrops are common in the basin. The area has been glaciated; till of varying thickness covers much of the higher terrain, and stratified drift and alluvium are found in low-lying areas (Westchester County, 1978).

\section{Climate}

The average annual precipitation in the Saw Mill River basin is 46.2 in. (U.S. Army Corps of Engineers, 1979). The mean annual temperature is $52^{\circ} \mathrm{F}$ (Westchester County, 1978).

\section{Streamflow}

The U.S. Geological Survey has maintained a gaging station (no. 01376500) on the Saw Mill River at Yonkers since 1944 ( $f$ ig. 1 ). It has been operated continuously since that time except during the first 6 months of the 1974 water year. (The water year extends from October 1 through September 30 of the following calendar year and is identified by the latter year.) The gaging station is $1.2 \mathrm{mi}$ from the mouth of the river, and the drainage area above the gage is $25.6 \mathrm{mi}^{2}$. From August 1978 to September 1982, the gaging station was temporarily relocated $1,300 \mathrm{ft}$ downstream from its permanent site because of channel construction. (The effective drainage area above the gage was not significantly changed.) Over the period of record (1944-82), mean discharge of the Saw Mill River at the gage has been $32.3 \mathrm{ft}^{3} / \mathrm{s}$, and 80 percent of the daily discharges were between 2.7 and $74.0 \mathrm{ft}^{3} / \mathrm{s}$. The recorded minimum daily discharge is $0.11 \mathrm{ft} / \mathrm{s}$, and the recorded maximum instantaneous discharge is $1,020 \mathrm{ft}^{3} / \mathrm{s}$. The annual extreme high flow can occur at any time during the year. The maximum monthly-mean flow typically occurs in March; the minimum monthly-mean flow is typically in summer or early fall. The monthly mean discharges during 1981 and 1982 are shown in fig. 3.

The discharge of the Saw Mill River at the gage does not include upstream diversions out of the basin by water users. In 1982 , for example, $6.26 \mathrm{ft}^{3} / \mathrm{s}$ was the average diversion out of the basin. This amount plus the gaged mean discharge of $28.9 \mathrm{ft}^{3} / \mathrm{s}$ is the total yield of the basin.

Two major impoundments are maintained on the Saw Mill drainage--the Tarrytown Reservoir and Woodlands Lake. The reservoir is on a tributary (fig. 1) and serves as a public water supply for the Village of Tarrytown, which withdrew $266 \mathrm{Mgal}$ during the 1982 water year (Board of Water and Sewer Commissioners, Village of Tarrytown, written commun., 1982). Woodlands Lake is in a ccunty park. A third, smaller impoundment is maintained by the City of Yonkers at river mile 3.2 for a water-treatment-plant intake. During the 1982 water year, 1,207 Mgal of water was withdrawn at this site; monthly mean withdrawals ranged from $5.71 \mathrm{Mgal} / \mathrm{d}$ in December to $0.21 \mathrm{Mgal} / \mathrm{d}$ in July (James Neary, City of Yonkers Water Supt., written commun., 1982).

Sections of the Saw Mill River have experienced repeated flooding. Consequently, the U.S. Army Corps of Engineers has undertaken several flood-control projects in recent years. One of these, which was in progress during 
this study, included construction of a concrete channel on a 1.5-mi section of the river in the City of Yonkers. Now completed, the channel is $20 \mathrm{ft}$ wide with 10-ft walls and extends from river mile 1.4 to 2.9. Possible effects of the channel modifications on the results of this study are discussed later.

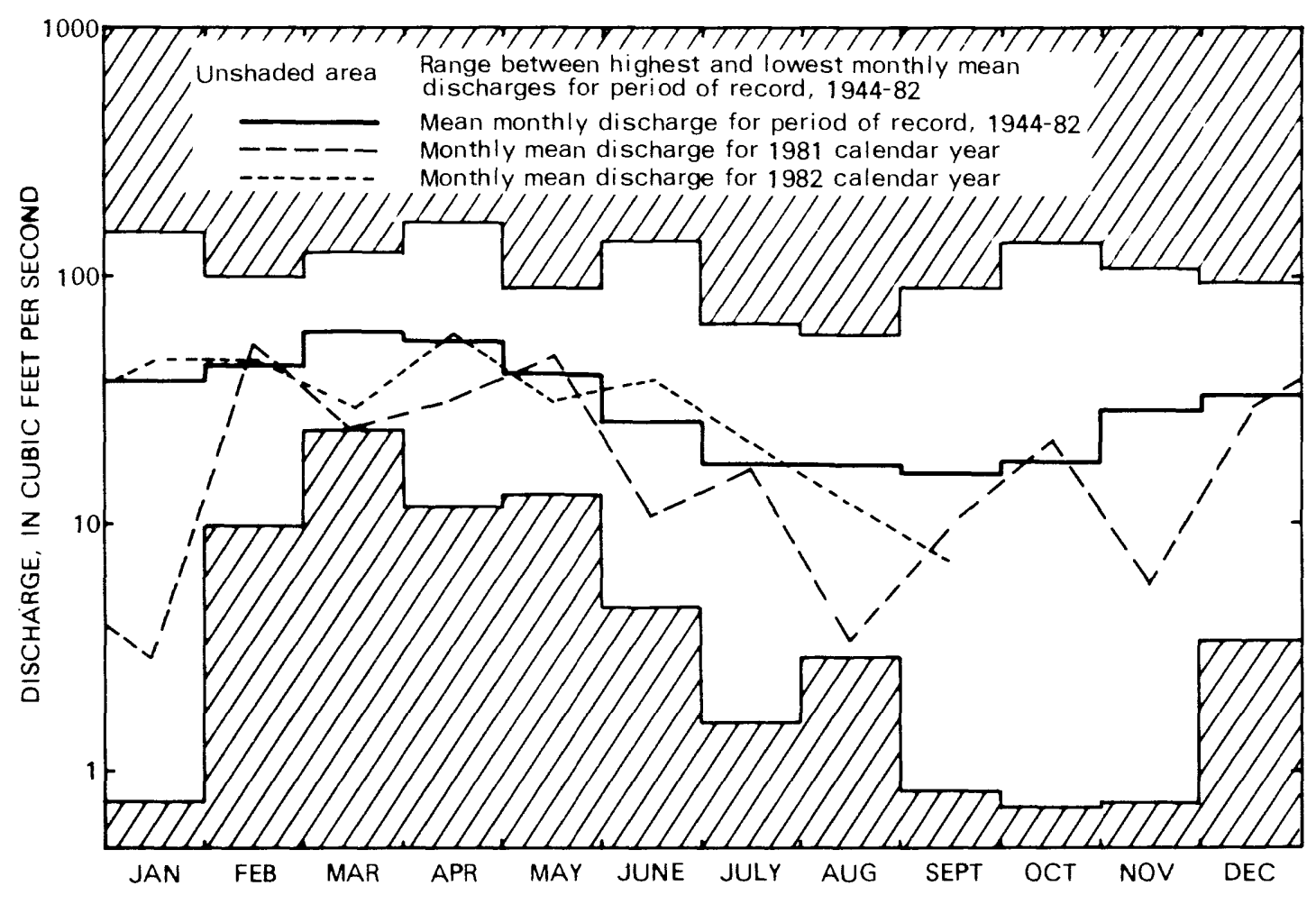

Fugure 3.--Monthly streamflow of the Saw Mill River at Yonkers.

\section{River Quality}

The State of New York uses a stream-classification system to define stream-water quality and regulate stream use (New York State Department of Environmental Conservation, 1974). The system, which is based on seven physical and chemical standards, defines the best use of the water and provides a basis for regulating the discharge of effluents that could lower the water quality. The system contains five classes ranging from AA to D. Classes AA and $A$ are suitable for drinking-water supplies and all other uses; class $B$ is suitable for bathing and other uses except as a drinking-water supply; class $C$ is suitable for fishing and other uses except bathing and as a drinking-water supply, and class $D$ is suitable for agriculture and industrial cooling and process water and other uses except fishing, bathing, and as a source of drinking water.

The Saw Mill River has been categorized under this system (Westchester County, 1978). The lower reach up to about river mile 3.0 is classified as $D$; the reach between river miles 3.0 and 9.0 is classified as $A$, and the reach above river mile 9 is classified as $B$. 


\section{Land Uso}

Approximately 100,000 people inhabit the Saw Mil1 River basin, which is mostly urban (Westchester County, 1978). Impervious surfaces cover 38 percent of the basin, but the percentage in the lower basin is much higher than this (Westchester County, 1978). Parks and smal1 wooded areas are most abundant in the northern part. Commercial establishments are scattered throughout the basin; industry is confined primarily to the City of Yonkers, below river mile 4.0. The Saw Mill River Parkway parallels the river along most of its length. The lower few miles of the river are often littered with debris such as tires, shoping carts, bottles, and other trash.

\section{DATA COLLECTION}

\section{Sampling Media and Sample Collection}

River-bottom sediments were the most extensively used sampling medium in this study for several reasons. Sediments sorb and concentrate heavy metals, nutrients, and many organic compounds, such as pesticides, that enter a river system (Feltz, 1980). Through sorption of such constituents, sediments provide a history of the quality of the water that flows over them. Further comparison of bottom-sediment chemistry among different sites reveals the distribution of constituents in the river and can thus help identify source areas of contaminants. The value of bottom-sediment analysis in determining concentration and distribution of chemical constituents has been demonstrated by many workers, including Rickert and others (1977), Qasim and others (1980), and Lopez-Avila and Hites (1980). Furthermore, contaminants that accumulate in bottom sediments are available to aquatic 1 ife and may reach toxic levels. Thus, the chemistry of bottom-sediments provides a measure of river quality.

River water is, in several respects, a less effective sampling medium than bottom sediments for revealing many chemical constituents. First, water samples represent only an instant in time and thus may fail to indisate contaminants from intermittent discharges. Also, compounds that may become highly concentrated in sediment may have 1 ow concentrations in water, often below analytical detection limits, and water analyses for these compounds may fail to indicate the river's true condition. For these reasons, most of the sampling in this study was directed to bottom materials rather than river water.

\section{Bottom Sediments}

Size fractions. - The concentration of acid-soluble metals in sediment is a function of grain size. (Acid-soluble metals are those solubilized in dilute hydrochloric acid and generally do not include those incorporated in the crystal lattice of the mineral grains.) The relationship between metal concentrations and grain size follows a bimodal distribution. Whitney (1975) found that in five streams in eastern New York, the maximum concentrations of metals were in the silt and clay fraction ( $<63 \mu \mathrm{m}$ diameter), with secondary highs in the coarse sand and fine gravel $(>1,000 \mu \mathrm{m}$ diameter). This bimodal distribution results from both the composition of the sediment, which varies with grain size, and the chemical mechanisms that bind the metals to the sediment (Whitney, 1975). 
The use of a narrowly defined size fraction of bottom sediments to compare metal concentrations among sites reduces variability caused by site-tosite differences in the grain-size distribution of the sediments. Silt and clay fractions are commonly used to investigate heavy metals or other contaminants in bottom sediments because the fine sediments contain the highest metal concentrations. In this study, however, sediment in the $1,000-$ to $2,000-\mu \mathrm{m}$ range was selected (1) because it is less subject to transport than fine sediment and therefore better reflects source areas of heavy metals, as Wilber and Hunter (1979a) documented, and (2) because many reaches of the Saw Mill River are fast moving and have a gravelly or rocky bottom, which makes collection of enough fine sediment for analysis difficult.

Sampling procedures and locations.--Bottom-sediment samples were collected in the streambed at the center of flow where possible. At some sites, however, where fast-moving water keeps the channel scoured, sand and finer sediment could be collected only immediately downstream from boulders or in quieter pools close to the banks. The cobble- and boulder-covered bottom at many sites precluded use of standard bed-material samplers. Therefore, samples were collected at all sites with either a plastic spoon or directly with the sample container. Al 1 sampling was done after periods of moderate to low flow, and only the top inch or less of sediment was sampled.

Bottom sediments were sampled at 20 sites, three of which were on tributaries ( $f i g .1$ ). Some of these sites were used for surface-water and soil sampling also. Sites were selected to provide coverage of the entire river basin ( $f i g .1$ and table 1 ) and were spaced more closely in the lower reaches to provide detailed coverage of the industrialized area. All sites are designated by an eight-digit U.S. Geological Survey downstream-order identification number, but in this report only the last three digits are used for identification.

Heavy metals.--Ten of the 20 sites were sampled for heavy metals more than once; in total, 36 samples of 1,000- to 2,000- $\mu \mathrm{m}$ sediment were analyzed for heavy metals. To establish the relationship between concentrations and grain size in the Saw Mill River, bottom-sediment samples from six sites ( 310 , $320,450,460,495$, and 503) were separated into six size fractions, and each fraction was analyzed for açid-soluble metals. Whole-sediment samples from these sites were also analyzed. (In this report, whole sediment refers to all sediment less than $2,000 \mu \mathrm{m}$ )

Organic Compounds.--Bottom sediments were also used to investigate the distribution of synthetic organic compounds in the river. Whole-sediment samples were used for this purpose. Most of the organic compounds investigated are on the USEPA 1 ist of "priority pollutants" (Keith and Te1liard, 1979). Twelve sites $(308,310,320,390,410,420,440,450,460,475,495,503)$ were sampled for pesticides and polychlorinated biphenyls (PCB's); two of these were sampled twice. Bottom sediments at eight sites $(320,410,420,450,470$, 495 , 503) were sampled for acid- and base/neutral-extractable organic compounds; two of these sites were also sampled twice. (Acid-extractable compounds are extracted with methylene chloride from sediment and water samples under acid conditions prior to analysis; base/neutral-extractable compounds are extracted similarly but under alkaline conditions.) 
Nutrients.--Bottom sediments were also analyzed for the major nutrients-nitrogen, phosphorus, and organic carbon. Nutrient analyses were performed on bottom sediment from all but the uppermost site. As with the heavy metals, whole sediment, 1,000- to 2,000- $\mu \mathrm{m}$ sediment, and, from selected sites, finer sediment fractions were analyzed.

Cyanide.--Samples of 1,000- to 2,000- $\mu$ m bottom sediment from 13 sites $(310,313,330,370,417,440,443,460,470,475,495,501,503)$ and samples of al1 six size fractions from two sites $(460,495)$ were analyzed for cyanide.

Table 1.--Location of the 20 sampling sites on the Saw Mill River and tributaries.

[Locations are shown in fig. 1]

Site

i denti-

fication

number ${ }^{1}$

Site name

Latitude

Longitude

01376308

Saw Mill River northwest of Chappaqua

$41^{\circ} 10^{\prime} 36^{\prime \prime}$

$73^{\circ} 46^{\prime} 47^{\prime \prime}$

01376310

Saw Mill River at Chappaqua

01376313

Tercia Brook at Chappaqua

01376320

Saw Mill River at Pleasantville

01376330

Saw Mi11 River at Thornwood

$41^{\circ} 09^{\prime} 50^{\prime \prime}$

$73^{\circ} 46^{\prime} 41^{\prime \prime}$

$41^{\circ} 09^{\prime} 23^{\prime \prime}$

$73^{\circ} 46^{\prime} 36^{\prime \prime}$

$41^{\circ} 07^{\prime} 55^{\prime \prime}$

$73^{\circ} 47^{\prime} 47^{\prime \prime}$

$41^{\circ} 07^{\prime} 28^{\prime \prime}$

$73^{\circ} 47^{\prime} 03^{\prime \prime}$

01376370

Nanny Hagen Brook at Thornwood

01376390

Saw Mill River at Hawt horne

01376410

Saw Mil1 River at Eastview

01376415

Saw Mill River near Elms ford

01376417 Mine Brook at Elms ford

$41^{\circ} 07^{\prime} 23^{\prime \prime} \quad 73^{\circ} 46^{\prime} 55^{\prime \prime}$

$41^{\circ} 06^{\prime} 29^{\prime \prime} 73^{\circ} 48^{\prime} 11^{\prime \prime}$

$41^{\circ} 04^{\prime} 48^{\prime \prime} 73^{\circ} 49^{\prime} 39^{\prime \prime}$

$41^{\circ} 03^{\prime} 58^{\prime \prime} \quad 73^{\circ} 49^{\prime} 06^{\prime \prime}$

$41^{\circ} 03^{\prime} 57^{\prime \prime} 73^{\circ} 49^{\prime} 00^{\prime \prime}$

01376420

Saw Mi11 River at E1ms ford

01376440

01376443

Saw Mil1 River at Worthington

Saw Mill River at Woodlands Lake

$41^{\circ} 03^{\prime} 19^{\prime \prime} 73^{\circ} 49^{\prime} 15^{\prime \prime}$

$41^{\circ} 01^{\prime} 51^{\prime \prime} 73^{\circ} 50^{\prime} 37^{\prime \prime}$

01376450

Saw Mill River at Mount Hope

$41^{\circ} 01^{\prime} 23^{\prime \prime} 73^{\circ} 50^{\prime} 44^{\prime \prime}$

01376460

Saw Mill River at Grey Oaks at Yonkers

$40^{\circ} 59^{\prime} 09^{\prime \prime} 73^{\circ} 51^{\prime} 54^{\prime \prime}$

$40^{\circ} 57^{\prime} 58^{\prime \prime} 73^{\circ} 52^{\prime} 19^{\prime \prime}$

01376470 Saw Mil1 River at 01d Nepperhan Rd. at Yonkers

$40^{\circ} 57^{\prime} 18^{\prime \prime} \quad 73^{\circ} 52^{\prime} 28^{\prime \prime}$

01376475

01376495

Saw Mill River at Worth St. at Yonkers

$40^{\circ} 57^{\prime} 05^{\prime \prime}$

$73^{\circ} 52^{\prime} 41^{\prime \prime}$

Saw Mi11 River at Ashburton Ave. at Yonkers

$40^{\circ} 56^{\prime} 18^{\prime \prime}$

$73^{\circ} 53^{\prime} 05^{\prime \prime}$

01376501

Saw Mill River off Walsh Rd. at Yonkers

$40^{\circ} 56^{\prime} 17^{\prime \prime}$

$73^{\circ} 53^{\prime} 23^{\prime \prime}$

01376503

Saw Mill River at Elm St. at Yonkers

$40^{\circ} 56^{\prime} 03^{\prime \prime}$

$73^{\circ} 53^{\prime} 00^{\prime \prime}$

1 Only the last three digits are used for site identification

in this report. 
Although river water was of less concern than bottom sediments in this study, for reasons described earlier, water samples were collected on several different dates to provide information on the water quality of the river.

Chemical analyses.--Sixteen samples from eight sites $(310,320,420,440$,

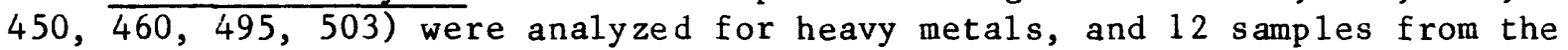
same eight sites for major nutrients. Dissolved and total concentrations of both metals and nutrients were measured. (Dissolved constituents are defined as those that pass through a $0.45-\mu \mathrm{m}$ filter.) Water samples collected at each of four sites $(320,420,460,503)$ on two dates were analyzed for total concentrations of pesticides, PCB's, and acid- and base/neutral-extractable organic compounds. In addition, nine samples from five sites (320, 420, 460, 495, 503 ) were analyzed for volatile organic compounds on the USEPA "priority pollutant" 1 ist, and 11 samples, one from each of 11 sites $(310,320,390$, $410,420,440,443,450,460,495,503)$, was analyzed for total phenols.

Sampling procedures.--A1 1 water samples were single-vertical-dip samples collected at the visual center of flow except at site 460 , where deep water in the impoundment required collection closer to the bank. Metal and nutrient samples were collected directly with a sample splitter and then distributed to bottles. Along most reaches, the stream was too shallow for depth-integrating collection techniques. Samples for organic carbon and nonvolatile organiccompound analyses were collected directly in the sample bottles; samples for volatile compounds were collected in glass septum bottles and capped under water to exclude air from the sample and prevent escape of volatiles.

(Volatile organic compounds are stripped as a vapor from the water sample by an inert gas prior to analysis.) All water samples were collected under moderate to low-flow conditions.

\section{Soizs}

Chemical analyses.--Soils are the source of stream-bottom sediments; consequently, the heavy-metals concentration in stream sediments is partly a function of the heavy-metals content of the soil particles that enter the stream. Soil samples from 10 sites $(320,410,415,440,450,460,470,495$, 501 , 503) were analyzed for five heavy metals to aid interpretation of the heavy-metal chemistry of the bottom sediments. Both 1,000- to 2,000- $\mu$ m soil fractions and whole soil $(<2,000 \mu \mathrm{m})$ were analyzed.

Sampling procedures.--Soil sites were selected to cover the entire length of the river and were more closely spaced in the lower section of the basin. Six of the sites are subject to direct runoff from roads, parking lots, or other impervious surfaces. Al 1 soil samples but one were collected along the Saw Mill River; the exception was collected near a small tributary that enters the river near site 410 ( $\mathrm{fig}$. 1). Al 1 samples were collected within $200 \mathrm{ft}$ of the river bank. The soil sites were assigned the same number as the closest river-sampling site.

The soil was sampled by first loosening the top 6 in. of soil with a steel shovel, then collecting by hand a sample of material that had not come into contact with the shovel. 
To complement the invectigation of the heavy-metal chemistry of the river, unglazed ceramic tiles were placed in the river for study of the accretion of iron-manganese oxides and associated heavy metals onto their surfaces. The method, which is considered experimental, is based on work by Carpenter and Hayes $(1978,1980)$, who proposed it as a geochemical exploration method. The technique is similar to using bottom sediments to assess river quality but eliminates four variables inherent to bottom-sediment assessments--substrate surface area, surface composition, site of accretion, and period of accretion. Some variability among sites remains, however; for example, the types of algal coatings that may develop on the substrates can vary with time and differ among sites. (Algae can serve to accumulate heavy metals (Laube and others, 1979) but also prevent the deposition of oxide coatings on the substrates.) Also, the tiles may become buried by sediment, which greatly reduces the rate of oxide deposition or may cause existing coatings to dissolve.

Unglazed ceramic tiles ( $2 \times 2$ in.) were used in the study. The tiles were prepared by simmering in concentrated hydrochloric acid for 3 hours and were then attached to an $8-x 8-x 14-i n$. concrete block by silicone rubber sealant. Each block contained 36 tiles. One block was placed in the river at each of seven sites: $320,410,443,450,470,495$, and 503. Blocks were lost at sites 470, 495, and 503 during the study; replacement sets were emplaced at sites 495 and 503. Four tiles were removed from each block at approximately 6 -week intervals. A control block of tiles identical to those used in the river was kept immersed in deionized water in the laboratory and was analyzed at the same interval as the field tiles.

\title{
Sample Preparation and Analyses
}

\author{
Sample Ereparation
}

Bottom Sediments.--Bottom sediments were prepared for chemical analysis by wet sieving. When only a whole-sediment or $1,000-$ to $2,000-\mu \mathrm{m}$ sample was required, the sample generally was sieved with river water at the site. Sediments that were separated into multiple size fractions, and those to be analyzed for pesticides, were sieved in the laboratory with river water collected at the time of sampling. In the laboratory, sediment was washed through sieves by repeatedly passing river water over them. The finest sediment was allowed to settle, and the water was then decanted. In addition to the 1,000- to 2,000- $\mu \mathrm{m}$ fraction, sediments from six sites were separated into the following fractions: 500- to $1,000-\mu \mathrm{m}, 250-$ to $500-\mu \mathrm{m}, 125-$ to $250-\mu \mathrm{m}$, 63- to $125-\mu \mathrm{m}$, and $<63-\mu \mathrm{m}$. A whole-sediment sample from all six sites was also prepared.

Sediment samples to be analyzed for nutrients, synthetic organic compounds, and cyanide were chilled from the time of collection; the other samples were stored at room temperature until analysis. Sediments to be analyzed for synthetic organic compounds were collected and stored in heattreated glass jars; all other sediment samples were stored in plastic containers. 
Soil.--Soil samples were sieved with deionized water in the laboratory and were stored at room temperature until analysis.

River water.--Water samples to be analyzed fu dissolved components were filtered through $0.45-\mu \mathrm{m}$ filters soon after collection. Silver filters were used for the dissolved organic carbon samples; membrane filters were used for al1 other samples. Samples to be analyzed for organic carbon and synthetic organic compounds were stored in heat-treated glass bottles. Samples for nitrogen and phosphorus analys is were preserved with mercuric chloride and stored in brown polyethylene bottles. Samples for metals analysis were acidified with nitric acid to $\mathrm{pH} 2$ or less and stored in polyethylene bottles. Samples for phenols analysis were preserved with copper sulfate and phosphoric acid and stored in glass bottles. Samples for synthetic organic compound analysis were collected and stored in heat-treated glass bottles. All water samples except those for metals analysis were chilled from the time of collection to the time of analysis.

Temperature, specific conductance, and $\mathrm{pH}$ were measured in the field at the time of sample collection.

Ceramic tiles.--Leachates from the ceramic tiles were prepared in the Geological Survey laboratory in Albany, N.Y. by a method similar to that described by Carpenter and Hayes (1978). In the laboratory, the backs of the tiles were scraped with a plastic knife to remove the silicone sealant and were cleaned further with silicon carbide paper to remove any precipitate from that surface. The tiles were then rinsed with deionized water and gently rubbed with the fingers to remove loosely adhered sediment and organic material, but not the oxide coating. After rinsing, they were placed in a beaker with $150 \mathrm{~mL}$ of dilute $(1: 4)$ hydrochloric acid and heated to $75^{\circ} \mathrm{C}$ for 4 hours. The resulting leachate was diluted to $500 \mathrm{~mL}$ with deionized water and analyzed for dissolved heavy metals.

\section{Cherical Analyses}

Al 1 chemical analyses were performed by the U.S. Geological Survey National Water Quality Laboratory in Doraville, Ga. Water, sediment, and soil samples were analyzed for heavy metals, cyanide, and nutrients by methods described in Skougstad and others (1979) and Fishman and Bradford (1982). Phenols in water were analyzed by the method described in Goerlitz and Brown (1972). Acid- and base/neutral-extractable organic compounds, listed in table 2 , were analyzed with a gas chromatograph/mass spectrometer by USEPA method 625 (U.S. Environmental Protection Agency, 1979b) or an adaptation of that method, which does not distinguish between anthracene and phenanthrene. Volatile organic compounds, 1 isted in table 3, were analyzed by a purge and trap technique and a GC/MS system (U.S. Environmental Protection Agency, 1979a). Pesticides and other chlorinated hydrocarbons, 1 isted in table 4, were analyzed with a gas chromatograph by an electron-capture detector (U.S. Environmental Protection Agency, 1979b; Goerlitz and Brown, 1972). The PCB analys is determined only gross concentration; it did not differentiate the Aroclors ${ }^{1}$. Organophosphorous pesticides ( $\left.t a b l e ~ 4\right)$ were analyzed with a gas chromatograph mated with a flame photometric detector.

1 Use of brand names herein is for identification purposes only. 
Grain-size andiyses of juttom sediments were done by dry sieving at the U.S. Geological Survey sediment laboratory in Columbus, Ohio. The size fractions measured were the same as those separated for chemical analyses.

Table 2.--Acid-and base/neutral-extractable oryanic compounds for which water and bottom-sediment samples were analyzed.

[Al1 compounds are on U.S. Environmental Protection Agency prioricypollutant 1ist; source: Beetem and others, 1981. Detection levels are approximately $1 \mathrm{\mu g} / \mathrm{L}$ for water plus suspended sediment and approximately $20 \mu \mathrm{g} / \mathrm{kg}$ for bottom sediment.]

\section{Acid-Extractable Organic Compounds}

4-Ch loro-3-methy 1 pheno 1

$2-$ Ch 1 orophenol

2, 4-Dich1 orophenol

2,4-Dimethyl phenol

4, 6-Dinitro-2-methy 1 phenol

2,4-Dinitrophenol

\author{
2-Nitrophenol \\ 4-Nitrophenol \\ Pentachlorophenol \\ Phenol \\ $2,4,6,-\operatorname{Tr}$ ichl or opheno 1
}

\section{Base/Neutra1-Extractable Organic Compounds}

Ac enaph thene

Ac enaph thylene

An thr acene

Benzidine

Benzo(a) anthracene

Benzo(b)fluoranthene

Benzo (k) fluoranthene

Benzo( $g, h, i)$ perylene

Benzo (a) pyrene

4-Bromophenyl phenyl ether

Butyl benzyl phthalate

Bi s (2-chl oroeth oxy)methane

$\mathrm{Bi}$ (2-chloroethyl) e ther

Bis (2-chl oroisopropy1) e ther

2-Ch loronaph thalene

4-Chlorophenyl phenyl ether

Chrysene

Di benzo $(a, h)$ anthracene

Di-n-butyl phthalate

1,2-Dichl orobenzene

1,3-Dichlorobenze ne

1,4-Dich lorobenzene

$3,3^{\prime}$-Di chlorobenzidine
Diethyl phthalate

Dimethyl phthalate

2,4-Dinitrotoluene

2, 6-Dinitrotoluene

Di-n-octy 1 phthalate

Bis (2-ethyl hexy 1) phthalate

Fluoranthene

Fluorene

Hexach 1 orobenzene

Hexach 1 orobutadiene

He xachl orocyclopentadiene

Hexach loroe thane

Indeno $(1,2,3-c d)$ pyrene

Is ophorone

Naphthalene

Nitrobenzene

Ni trosodime thyl amine

$n-\mathrm{Ni}$ tros od i pheny 1 amine

n-Ni trosodi-n-propylamine

Phenanthrene

Pyrene

$2,3,7,8-$ Te trachlorod ibenzo-p-dioxin

1, 2,4-Trichlorobenzene 
Table 3.--Principal volatile organic compounds for which water somples were analyzed.

[A11 compounds are on U.S. Environmental Protection Agency priority pollutant 1ist. Detection level

approximately is $1 \mu \mathrm{g} / \mathrm{L}$. Source: Beetem and others, 1981.]

\begin{tabular}{|c|c|}
\hline \multicolumn{2}{|c|}{ Volatile Organic Compounds } \\
\hline Benzene & 1,2-trans-D i ch loroethylene \\
\hline Bromoform & 1, 2-Dichlorop ropane \\
\hline Chlorobenzene & $\begin{array}{l}\text { 1, J-Dlcn loropropane } \\
\text { Ethyl benzene }\end{array}$ \\
\hline Ch lorod ibromome thane & Me thyl bromide \\
\hline Chloroe thane & Me thylene chloride \\
\hline 2 -Ch loroethyl vinyl ether & $1,1,2,2$-Tetrach 1 oroethane \\
\hline Ch loroform & Tetrachloroethylene \\
\hline Dichlorobromomethane & Toluene \\
\hline Dichlorodifluorome thane & $1,1,1$-Trich loroethane \\
\hline $1,1-D i$ chloroethane & $1,1,2-\operatorname{Tr}$ ichloroethane \\
\hline 1,2-Dichloroethane & Trichloroethylene \\
\hline $1,1-$ i chloroethyl ene & Trichlorofluoromethane \\
\hline
\end{tabular}

Table 4.--Organochlorine and organophosphorous compounds for which water and bottom-sediment samples were analyzed.

[NA - water samples not analyzed for these compounds. Source: Beetem and others, 1981.]

\begin{tabular}{|c|c|c|}
\hline \multirow[b]{2}{*}{ Compound } & \multicolumn{2}{|c|}{ Detection level } \\
\hline & $\begin{array}{c}\text { Water plus suspended } \\
\text { sediment }(\mu \mathrm{g} / \mathrm{L})\end{array}$ & $\begin{array}{c}\text { Bottom sediment } \\
(\mu \mathrm{g} / \mathrm{kg})\end{array}$ \\
\hline Aldrin & 0.01 & 0.1 \\
\hline Ch lordane & .1 & 1 \\
\hline DDD & .01 & .1 \\
\hline $\mathrm{DDE}$ & .01 & .1 \\
\hline DDT & .01 & .1 \\
\hline Diazinon & NA & .1 \\
\hline Dieldrin & .01 & .1 \\
\hline Endosulfan & .01 & .1 \\
\hline Endrin & .01 & .1 \\
\hline Ethion & NA & .1 \\
\hline Gross PCB & .1 & 1 \\
\hline Gross PCN & .1 & 1 \\
\hline Heptach lor & .01 & .1 \\
\hline Heptachlor epoxide & .01 & .1 \\
\hline Lindane & .01 & .1 \\
\hline Malathion & $\mathrm{NA}$ & .1 \\
\hline Me thoxychlor & .01 & .1 \\
\hline Methy 1 parathion & NA & .1 \\
\hline Methyl trithion & NA & .1 \\
\hline Mirex & .01 & .1 \\
\hline Perthane & .1 & .1 \\
\hline Parathion & NA & .1 \\
\hline Toxaphene & 1 & 1 \\
\hline Trithion & NA & .1 \\
\hline
\end{tabular}




\title{
CHEMICAL QUALITY OF SAW MILL RIVER
}

\section{Nutrients}

\author{
River Water
}

Nitrogen and phosphorus are commonly the nutrients that limit plant growth. Nitrogen, phosphorus, and carbon concentrations in water samples are presented in table 16 (at end of report). (As a consequence of normal analytical error, the dissolved concentration reported for a constituent is sometimes slightly greater than the total concentration of that constituent.) The generality of the following observations is restricted by the small number of analyses made for nutrients.

Dissolved forms of nitrogen constituted most, if not all, of the total concentration of the various nitrogen species in the water samples tested. By comparison, dissolved forms of phosphorus contributed a smaller percentage, about half, of the total phosphorus, and dissolved organic carbon contributed about 70 percent of the total organic carbon. The most abundant forms of nitrogen in the water samples were dissolved organic nitrogen ( 0.30 to 1.5 $\mathrm{mg} / \mathrm{L}$ as nitrogen) and dissolved nitrate ( 0.48 to $1.6 \mathrm{mg} / \mathrm{L}$ as nitrogen); minor by comparison were dissolved ammonia ( 0.03 to $0.44 \mathrm{mg} / \mathrm{L}$ as $n i t r o g e n)$ and dissolved nitrite $(0.01$ to $0.06 \mathrm{mg} / \mathrm{L}$ as nitrogen). Approximately 60 percent of the dissolved phosphorus was in the form of orthophosphate. Organic carbon concentrations were in the normal range for stream waters.

Neither nitrate, nitrite, nor un-ionized ammonia were detected in concentrations exceeding U.S. Envi ronmental Protection Agency (1977) waterquality criteria or New York State Department of Health (1977) standards for sources of water supplies.

Availability of nutrients can cause excessive algal growth, but many other factors limit algal growth, especially in streams. Consequently, no generally accepted standard to prevent nuisance growth have been established for nitrogen and phosphorus. Phosphorus concentrations of $0.1 \mathrm{mg} / \mathrm{L}$ or greater may interfere with coagulation processes in water-treatment plants (Mackenthun, 1973, p.123). A total phosphorus concentration of $0.1 \mathrm{mg} / \mathrm{L}$ been suggested as a desired goal for rivers that do not discharge into lakes or impoundments (Mackenthun, 1973, p. 176). Phosphorus concentrations in the Saw Mill River exceed $0.1 \mathrm{mg} / \mathrm{L}$ at times, but no excessive algal growth was apparent in the river.

\section{Bottom Sediments}

Nitrogen, phosphorus, and carbon concentrations in bottom sediments are presented in table 17 (at end of report). Analyses of multiple size fractions of bottom sediment from six sites indicate that the relationships between concentration and grain size for nitrogen, phosphorus, and organic carbon follow a bimodal distribution--that is, nutrient concentrations in the 1,000 - to $2,000-\mu \mathrm{m}$ sediment are greater than in 250 - to 1,000- $\mu \mathrm{m}$ fractions, but the highest concentrations are in fractions smaller than $250 \mu \mathrm{m}$. (Site 320 may be an exception.) Phosphorus and organic carbon show this bimodal relationship most strongly. 
Concentrations of nutrients in both water and sediments do not vary significantly among sites. The spatial variations follow no discernible trends except for dissolved orthophosphate, which was slightly more concentrated in the lower third of the river. Phosphates may enter rivers from several sources, including human and animal excrement, phosphate detergents, industrial wastewaters, and leaves.

\section{Heavy Metals}

\section{River Water}

Water analyses for heavy metais are presented in table 18 (at end of report). The data are 1 imited but suggest a downstream increase in heavy metals in the river water. A high percentage of the total heavy metals carried by the river is carried on suspended matter, especially iron, lead, and zinc, of which at least 85 percent is borne on suspended matter.

Manganese was the only metal that regularly exceeded the U.S. Envi ronmental Protection Agency (1977) water-quality criterion of $50 \mu \mathrm{g} / \mathrm{L}$ for domestic water supplies (which applies to the dissolved metal only). This 1 imit is based on esthetic, rather than health, considerations, namely that manganese concentrations greater than $150 \mathrm{\mu g} / \mathrm{L}$ can stain 1aundry and affect the taste of beverages. Manganese did not, however, exceed the New York State Department of Health (1977) standard of $300 \mu \mathrm{g} / \mathrm{L}$ for sources of water supplies, nor did any of the other metals investigated in this study.

Collectively the water analyses provide evidence of a downstream deterioration in water quality. The four highest concentrations of total recoverable lead and zinc and the two highest concentrations of dissolved lead and zinc were found in the lowest 4 miles of the river. The two highest concentrations of total-recoverable and dissolved copper were downstream of river mile 3. Three of the four cadmium concentrations above the detection limit $(1 \mu \mathrm{g} / \mathrm{L})$ and the only two arsenic concentrations above the detection limit (1 $\mu \mathrm{g} / \mathrm{L})$ were in samples collected downstream from river mile 4.

\section{Eottom Sediments}

Heavy-metal. concentrations in six size fractions of bottom sediment from six sites along we tul l length of che river are 1 isted in table 5 . All size fractions from four sites $(310,320,450$, and 503) were also analyzed for arsenic and mercury, but concentrations of these metals were below the detection 1 imits of 1 ug' and 0.01 ugis, respectively.

Concentration in relation tc sediment size. - The concentrations of aciasoluble metals are, in generai, highesi in the inest size fracion. Why decrease with increasing gain size over the next two or three fractions, but

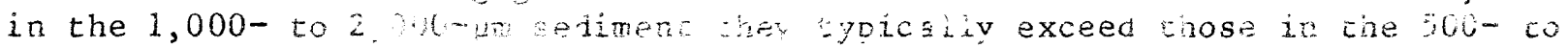

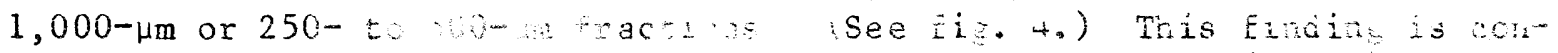

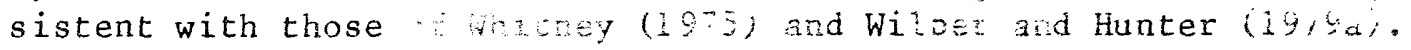


Table 5.--Heavy-metal concentrations is size fraction of bottom sediments from the Saw Mill River, 1981.

[Analyses by U.S. Geological Survey.

Concentrations in mícrograms per gram of dry

sediment; site locations shown in $\mathrm{ftg}$. l.]

\begin{tabular}{|c|c|c|c|c|c|c|c|c|c|}
\hline $\begin{array}{l}\text { Size } \\
\text { fraction } \\
\end{array}$ & $\begin{array}{l}\text { Site } \\
\text { number }\end{array}$ & $\begin{array}{l}\text { Dry-weight } \\
\text { percentage } \\
\text { in whole } \\
\text { sediment } 1 \\
\end{array}$ & $\mathrm{Cd}$ & $\mathrm{Cr}$ & $\mathrm{Cu}$ & $\mathrm{Fe}$ & $\mathrm{Pb}$ & $\mathrm{Mn}$ & $\mathrm{Zn}$ \\
\hline \multirow{6}{*}{$\begin{array}{l}1,000- \\
2,000 \quad \mu \mathrm{m}\end{array}$} & 310 & 4.2 & $<1$ & 20 & -- & 15,000 & 49 & 390 & - \\
\hline & 320 & 11.6 & 2 & $<10$ & 11 & 4,700 & 54 & 490 & 33 \\
\hline & 450 & 19.9 & $<1$ & 20 & 16 & 10,000 & 52 & 190 & 50 \\
\hline & 460 & 15.6 & $<1$ & $<10$ & $<10$ & 1,900 & 30 & 32 & 11 \\
\hline & 495 & 10.8 & $<1$ & $<10$ & 100 & 1,900 & 60 & 73 & 47 \\
\hline & 503 & 23.9 & 2 & $<10$ & 27 & 9,500 & 280 & 250 & 110 \\
\hline \multirow{6}{*}{$\begin{array}{l}500- \\
1,000 \quad \text { um }\end{array}$} & 310 & 33.9 & $<1$ & 10 & 15 & 5,000 & 14 & 160 & 30 \\
\hline & 320 & 33.7 & 1 & $<10$ & 5 & 2,600 & 38 & 210 & 24 \\
\hline & 450 & 37.4 & $<1$ & 25 & 31 & 6,000 & 38 & 120 & 50 \\
\hline & 460 & 21.0 & $<1$ & $<10$ & $<10$ & 1,900 & 10 & 30 & 7 \\
\hline & 495 & 27.4 & $<1$ & $<10$ & 100 & 1,800 & 70 & 72 & 94 \\
\hline & 503 & 38.7 & 1 & $<10$ & 100 & 4,800 & 150 & 260 & 110 \\
\hline \multirow{6}{*}{$\begin{array}{l}250- \\
500 \quad \mathrm{~m}\end{array}$} & 310 & 48.9 & $<1$ & $<10$ & 5 & 3,900 & 12 & 140 & 20 \\
\hline & 320 & 42.2 & 2 & $<10$ & 35 & 4,000 & 83 & 170 & 35 \\
\hline & 450 & 30.2 & $<1$ & $<10$ & 8 & 4,900 & 68 & 160 & 30 \\
\hline & 460 & 31.5 & $<1$ & $<10$ & $<10$ & 2,900 & 10 & 52 & 14 \\
\hline & 495 & 43.1 & $<1$ & $<10$ & 80 & 2,300 & 40 & 66 & 70 \\
\hline & 503 & 22.0 & 2 & $<10$ & 80 & 2,000 & 60 & 70 & 45 \\
\hline \multirow{6}{*}{$\begin{array}{l}125- \\
250 \quad \mathrm{~m}\end{array}$} & 310 & 8.3 & $<1$ & 40 & 26 & 14,000 & 68 & 460 & 90 \\
\hline & 320 & 10.5 & 2 & 20 & 23 & 10,000 & 330 & 350 & 90 \\
\hline & 450 & 9.6 & $<1$ & 20 & 12 & 12,000 & 120 & 500 & 40 \\
\hline & 460 & 21.6 & $<1$ & 10 & 10 & 5,400 & 20 & 88 & 26 \\
\hline & 495 & 15.1 & $<1$ & $<10$ & 130 & 3,000 & 140 & 73 & 77 \\
\hline & 503 & 7.8 & 2 & 10 & 140 & 5,500 & 180 & 140 & 110 \\
\hline \multirow{6}{*}{$\begin{array}{l}63- \\
125 \quad \mathrm{~m}\end{array}$} & 310 & 1.7 & $<1$ & 100 & 110 & 30,000 & 140 & 900 & 230 \\
\hline & 320 & 1.3 & 7 & 90 & 43 & 6,500 & 270 & 290 & 120 \\
\hline & 450 & 1.4 & $<1$ & 50 & 30 & 11,000 & 87 & 590 & 110 \\
\hline & 460 & 6.2 & 1 & 30 & 20 & 14,000 & 60 & 270 & 87 \\
\hline & 495 & 2.3 & $<1$ & 30 & 230 & 8,100 & 560 & 220 & 140 \\
\hline & 503 & 4.4 & 6 & 20 & 74 & 9,700 & 230 & 210 & 150 \\
\hline \multirow[t]{6}{*}{$<63$ im } & 310 & 2.9 & 3 & 60 & 39 & 25,000 & 110 & 840 & 180 \\
\hline & 320 & 0.8 & 11 & 150 & 210 & 25,000 & 350 & 1,200 & 520 \\
\hline & 450 & 1.4 & $<1$ & 80 & 88 & 28,000 & 280 & 2,000 & 300 \\
\hline & 460 & 4.1 & $<1$ & 65 & 60 & 24,000 & 170 & 680 & 220 \\
\hline & 495 & 1.3 & 3 & 60 & 500 & 23,000 & 570 & 830 & 470 \\
\hline & 503 & 3.2 & 5 & 50 & 170 & 18,000 & 440 & 560 & 400 \\
\hline \multirow[t]{6}{*}{$<2,000$ in } & 310 & -- & $<1$ & 10 & 6 & 7,100 & 27 & 220 & 30 \\
\hline & 320 & -- & 1 & 20 & 75 & 11,000 & 240 & 330 & 130 \\
\hline & 450 & -- & $<1$ & 10 & 11 & 5,000 & 58 & 100 & 40 \\
\hline & 460 & -- & $<1$ & $<10$ & 10 & 4,300 & 30 & 100 & 33 \\
\hline & 495 & -- & $<1$ & $<10$ & 90 & 2,400 & 80 & 75 & 78 \\
\hline & 503 & -- & 1 & 10 & 81 & 6,800 & 160 & 180 & 150 \\
\hline
\end{tabular}

1 Whole sediment $=\langle 2,000 \mathrm{~m}$. 
The higher metal concentrations in 1,000- to 2,000- $\mu \mathrm{m}$ sediment are attributed to thicker iron- and manganese-oxide coatings on the coarse sediment than on the fine sediment (Whitney, 1975) and may be attributed to heavier coatings of organic matter on the larger grains as well. Conditions for oxide deposition and associated heavy-metal sorption have been found generally more favorable in shallow, fast-flowing reaches of streams than elsewhere (Whitney, 1975). Site 320, in the upper 3 miles of the river, and site 503, the lowermost site, for example, are on shallow, swift reaches with sand and gravel bottoms, and the relationship between concentration and grain size for these sites, plotted in figure 4, is clearly bimodal. Site 460, conversely, is on a reach that is impounded for the City of Yonkers water-treatment plant (fig. 1 ). The water here is relatively deep $(>3 \mathrm{ft}$ ) and slow moving, and the bottom sediment at the site has a relatively high silt and clay content. (See table 6.) Concentrations of heavy metals in the 1,000- to 2,000- $\mu \mathrm{m}$ sediment at this site were much lower than in the finer sediments.

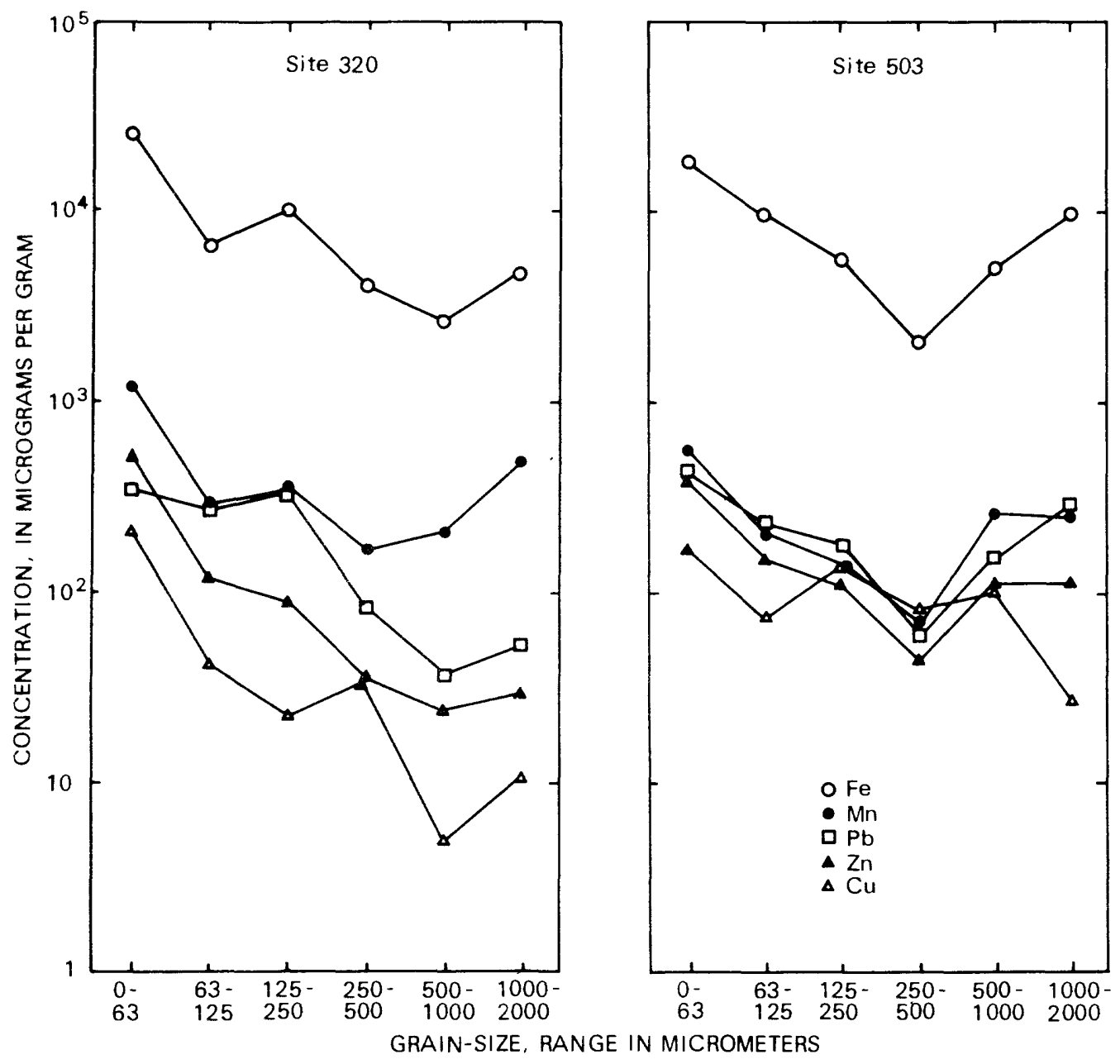

Figure 4.--Relation of heavy-metal concentration to sediment grain size at site 320, near upper end of basin, and site 503, near lower end of basin. 
The sediment fraction having the greatest quantities of heavy metals in the entire river is the 250- to $1,000-\mu \mathrm{m}$ range, the most abundant sediment size. Concentrations at all sites are given in table 5; the particle-size distribution at all sites is summarized in table 6.

Table 6.--Dry-weight percentage of sediment size fractions in river bottom sediments from Saw Mill River and tributaries, 1981.

[Site locations are shown in fig.1]

\begin{tabular}{|c|c|c|c|c|c|c|c|}
\hline \multirow[b]{2}{*}{$\begin{array}{l}\text { Site } \\
\text { number }\end{array}$} & \multirow[b]{2}{*}{$\begin{array}{c}\text { Date } \\
\text { collected }\end{array}$} & \multicolumn{4}{|c|}{ Particle-size range } & \multicolumn{2}{|c|}{$\mu \mathrm{m})$} \\
\hline & & $\begin{array}{l}1,000- \\
2,000\end{array}$ & $\begin{array}{r}500- \\
1,000 \\
\end{array}$ & $\begin{array}{l}250- \\
500 \\
\end{array}$ & $\begin{array}{l}25- \\
250 \\
\end{array}$ & $\begin{array}{r}63- \\
125 \\
\end{array}$ & $<63$ \\
\hline 310 & $05-12-81$ & 4.2 & 33.9 & 48.9 & 8.3 & 1.7 & 2.9 \\
\hline 313 & $08-12-81$ & 15.8 & 26.2 & 29.9 & 13.1 & 6.6 & 8.3 \\
\hline $\begin{array}{l}320 \\
330\end{array}$ & $\begin{array}{l}02-10-81 \\
08-11-81\end{array}$ & $\begin{array}{r}11.6 \\
8.8\end{array}$ & $\begin{array}{l}33.7 \\
38.5\end{array}$ & $\begin{array}{l}42.2 \\
38.4\end{array}$ & $\begin{array}{r}10.5 \\
9.4\end{array}$ & $\begin{array}{l}1.3 \\
3.0\end{array}$ & $\begin{array}{r}.8 \\
2.0\end{array}$ \\
\hline 370 & $08-11-81$ & 19.4 & 45.1 & 29.2 & 5.5 & .4 & .4 \\
\hline 390 & $05-11-81$ & ${ }^{1} \mathrm{SD}$ & --- & --- & --- & --- & --- \\
\hline 410 & $05-11-81$ & 21.9 & 30.5 & 33.3 & 11.7 & 1.8 & .9 \\
\hline 415 & $08-11-81$ & 6.8 & 33.6 & 43.6 & 12.9 & 1.0 & 2.0 \\
\hline 417 & $08-11-81$ & 26.4 & 38.1 & 27.9 & 6.5 & .7 & .3 \\
\hline 420 & $05-11-81$ & 11.3 & 47.7 & 37.2 & 3.2 & .3 & .3 \\
\hline 440 & $05-11-81$ & 16.7 & 44.2 & 22.0 & 12.0 & 2.4 & 2.7 \\
\hline 450 & $05-11-81$ & 19.9 & 37.4 & 30.8 & 9.6 & 1.4 & 1.4 \\
\hline 460 & $08-12-81$ & 15.6 & 21.0 & 31.2 & 21.6 & 6.2 & 4.1 \\
\hline 470 & $08-12-81$ & 35.1 & 29.5 & 22.9 & 8.8 & 2.7 & 1.1 \\
\hline 475 & $05-11-81$ & 26.0 & 27.8 & 37.2 & 7.4 & .7 & 1.0 \\
\hline 495 & $08-12-81$ & 10.8 & 27.4 & 43.1 & 15.1 & 2.3 & 1.3 \\
\hline 501 & $08-12-81$ & 16.6 & 32.4 & 40.6 & 9.2 & .7 & .4 \\
\hline 503 & $02-10-81$ & 23.9 & 38.7 & 22.0 & 7.8 & 4.4 & 3.2 \\
\hline
\end{tabular}

$1 \mathrm{SD}=$ Sample destroyed by 1aboratory.

Concentration patterns.--Analyses of 36 samples of $1,000-$ to $2,000-\mu \mathrm{m}$ bottom sediment from all sites are presented in table 7. Concentrations of arsenic, cadmium, chromium, cobalt, mercury, and nickel were, in general, near or less than their respective analytical detection limits. Marked differences were found within sites where multiple samples were collected, which demonstrates the qualitative nature of bottom-sediment chemistry. Some of the variation at site 495 (river mile 1.5) may be a consequence of the aforementioned channel construction at and near the site. 
Table 7.--Heavy-metal concentrations in 1,000- to 2,000-um bottom sediment from the Saw Mill River and tributaries, 1981-82. [Analyses by U.S. Geological Survey. Concentrations in micrograms per gram of dry sediment; site locations are shown in fig. 1.]

\begin{tabular}{|c|c|c|c|c|c|c|c|c|c|c|c|c|}
\hline $\begin{array}{l}\text { Site } \\
\text { number }\end{array}$ & $\begin{array}{c}\text { Date } \\
\text { collected } \\
\end{array}$ & As & $\mathrm{Cd}$ & $\mathrm{Cr}$ & Co & $\mathrm{Cu}$ & $\mathrm{Fe}$ & $\mathrm{Pb}$ & $\mathrm{Mn}$ & $\mathrm{Hg}$ & N1 & $2 n$ \\
\hline 308 & $11-17-81$ & -- & $<1$ & 9 & -- & 2 & 3,300 & 10 & 240 & - & 20 & 23 \\
\hline 310 & $\begin{array}{l}05-12-81 \\
08-12-81\end{array}$ & $\begin{array}{l}<1 \\
--\end{array}$ & $\begin{array}{l}<1 \\
<1\end{array}$ & $\begin{array}{r}20 \\
<10\end{array}$ & $-\overline{10}$ & $\overline{10}$ & $\begin{array}{r}15,000 \\
6,000\end{array}$ & $\begin{array}{l}49 \\
90\end{array}$ & $\begin{array}{l}390 \\
190\end{array}$ & $\begin{array}{c}<0.01 \\
--\end{array}$ & -- & -- \\
\hline 313 & $08-12-81$ & -- & 1 & 10 & 10 & 10 & 5,800 & 20 & 200 & -- & 10 & 42 \\
\hline 320 & $\begin{array}{l}02-10-81 \\
05-11-81 \\
08-24-82\end{array}$ & $\begin{array}{l}<1 \\
<1 \\
--\end{array}$ & $\begin{array}{r}2 \\
4 \\
<1\end{array}$ & $\begin{array}{r}<10 \\
30 \\
3\end{array}$ & $\begin{array}{l}-- \\
-- \\
<10\end{array}$ & $\begin{array}{r}11 \\
18 \\
4\end{array}$ & $\begin{array}{l}4,700 \\
9,300 \\
1,000\end{array}$ & $\begin{array}{l}54 \\
93 \\
20\end{array}$ & $\begin{array}{l}490 \\
260 \\
150\end{array}$ & $\begin{array}{l}<.01 \\
<.01 \\
--\end{array}$ & -- & $\begin{array}{l}33 \\
70 \\
25\end{array}$ \\
\hline 330 & $08-11-81$ & -- & 1 & $<10$ & $<10$ & 10 & 4,300 & 20 & 96 & -- & 10 & 33 \\
\hline 370 & $08-11-81$ & - & 1 & $<10$ & $<10$ & 10 & 4,000 & 70 & 240 & -- & $<10$ & 33 \\
\hline 390 & $08-11-81$ & $<1$ & 1 & $<10$ & -- & 12 & 8,700 & 23 & 160 & $<.01$ & $-\infty$ & 40 \\
\hline 410 & $\begin{array}{l}05-11-81 \\
08-24-82\end{array}$ & $<1$ & $\begin{array}{l}<1 \\
<1\end{array}$ & $\begin{array}{r}<10 \\
2\end{array}$ & $<10$ & $\begin{array}{r}12 \\
2\end{array}$ & $\begin{array}{r}9,800 \\
880\end{array}$ & $\begin{array}{l}21 \\
10\end{array}$ & $\begin{array}{l}310 \\
220\end{array}$ & $\begin{array}{l}<.01 \\
--\end{array}$ & $<-$ & $\begin{array}{l}50 \\
17\end{array}$ \\
\hline 415 & $08-11-81$ & -- & $<1$ & $<10$ & $<10$ & 10 & 5,500 & 10 & 150 & -- & 10 & 37 \\
\hline 417 & $08-11-81$ & - & $<1$ & 10 & 10 & 10 & 4,300 & 30 & 150 & -- & 10 & 56 \\
\hline 420 & $08-12-81$ & $<1$ & $<1$ & 10 & -- & 15 & 11,000 & 42 & 340 & $<.01$ & -- & 80 \\
\hline 440 & $\begin{array}{l}05-11-81 \\
08-12-81\end{array}$ & $<1$ & $\begin{array}{l}<1 \\
<1\end{array}$ & $\begin{array}{ll}<1 & 0 \\
<1 & 0\end{array}$ & $<10$ & $\begin{array}{r}9 \\
10\end{array}$ & $\begin{array}{l}6,800 \\
5,700\end{array}$ & $\begin{array}{r}110 \\
20\end{array}$ & $\begin{array}{r}120 \\
96\end{array}$ & $\begin{array}{l}<.01 \\
--\end{array}$ & -- & $\begin{array}{l}40 \\
39\end{array}$ \\
\hline 443 & $\begin{array}{l}09-01-81 \\
08-24-82\end{array}$ & -- & $\begin{array}{l}<1 \\
<1\end{array}$ & $\begin{array}{l}8 \\
6\end{array}$ & $\begin{array}{l}<10 \\
<10\end{array}$ & $\begin{array}{r}9 \\
33\end{array}$ & $\begin{array}{l}5,100 \\
2,200\end{array}$ & $\begin{array}{l}25 \\
30\end{array}$ & $\begin{array}{l}320 \\
180\end{array}$ & $\begin{array}{l}-- \\
--\end{array}$ & $\begin{array}{r}10 \\
<10\end{array}$ & $\begin{array}{l}33 \\
24\end{array}$ \\
\hline 450 & $\begin{array}{l}05-11-81 \\
08-24-82\end{array}$ & $\begin{array}{l}<1 \\
--\end{array}$ & $\begin{array}{l}<1 \\
<1\end{array}$ & $\begin{array}{r}20 \\
8\end{array}$ & $<10$ & $\begin{array}{r}16 \\
5\end{array}$ & $\begin{array}{r}10,000 \\
1,500\end{array}$ & $\begin{array}{l}52 \\
20\end{array}$ & $\begin{array}{r}190 \\
84\end{array}$ & $<.01$ & $<\overline{10}$ & $\begin{array}{l}50 \\
19\end{array}$ \\
\hline 460 & $08-12-81$ & -- & $<1$ & $<10$ & $<10$ & $<10$ & 1,900 & 30 & 32 & - & $<10$ & 11 \\
\hline 470 & $\begin{array}{l}08-12-81 \\
08-24-82\end{array}$ & -- & $\begin{array}{l}1 \\
<1\end{array}$ & $\begin{array}{r}20 \\
6\end{array}$ & $\begin{array}{l}<10 \\
<10\end{array}$ & $\begin{array}{l}70 \\
45\end{array}$ & $\begin{array}{r}4,800 \\
920\end{array}$ & $\begin{array}{l}90 \\
50\end{array}$ & $\begin{array}{r}200 \\
82\end{array}$ & -- & $\begin{array}{r}10 \\
<10\end{array}$ & $\begin{array}{r}190 \\
33\end{array}$ \\
\hline 475 & $\begin{array}{l}05-11-81 \\
08-12-81\end{array}$ & $<1$ & $\begin{array}{l}<1 \\
<1\end{array}$ & $\begin{array}{l}10 \\
10\end{array}$ & $<10$ & $\begin{array}{l}37 \\
20\end{array}$ & $\begin{array}{r}10,000 \\
4,900\end{array}$ & $\begin{array}{r}140 \\
90\end{array}$ & $\begin{array}{l}200 \\
120\end{array}$ & $<.01$ & $<-$ & $\begin{array}{l}90 \\
94\end{array}$ \\
\hline 495 & $\begin{array}{l}05-11-81 \\
08-12-81 \\
11-17-81 \\
04-21-82 \\
08-24-82\end{array}$ & $\begin{array}{l}<1 \\
-- \\
-- \\
-- \\
--\end{array}$ & $\begin{array}{r}3 \\
<1 \\
<1 \\
<4 \\
1\end{array}$ & $\begin{array}{r}70 \\
<10 \\
7 \\
6 \\
10\end{array}$ & $\begin{array}{l}<10 \\
-- \\
<10 \\
<10\end{array}$ & $\begin{array}{r}83 \\
100 \\
20 \\
340 \\
23\end{array}$ & $\begin{array}{r}12,000 \\
1,900 \\
2,800 \\
3,300 \\
2,400\end{array}$ & $\begin{array}{r}500 \\
60 \\
20 \\
50 \\
60\end{array}$ & $\begin{array}{r}460 \\
73 \\
88 \\
110 \\
180\end{array}$ & $\begin{array}{c}<.01 \\
-- \\
-- \\
-- \\
--\end{array}$ & $\begin{array}{r}-- \\
<10 \\
10 \\
<10 \\
10\end{array}$ & $\begin{array}{r}240 \\
47 \\
63 \\
230 \\
54\end{array}$ \\
\hline 501 & $08-12-81$ & -- & 2 & $<10$ & $<10$ & 50 & 5,200 & 470 & 140 & -- & 10 & 660 \\
\hline 503 & $\begin{array}{l}02-10-81 \\
05-11-81 \\
08-12-81 \\
08-24-82\end{array}$ & $\begin{array}{l}<1 \\
<1 \\
-- \\
--\end{array}$ & $\begin{array}{r}2 \\
<1 \\
1 \\
1\end{array}$ & $\begin{array}{r}<10 \\
10 \\
10 \\
3\end{array}$ & $\begin{array}{l}-- \\
<10 \\
<10\end{array}$ & $\begin{array}{l}27 \\
20 \\
50 \\
13\end{array}$ & $\begin{array}{r}9,500 \\
11,000 \\
5,500 \\
1,600\end{array}$ & $\begin{array}{r}280 \\
33 \\
120 \\
70\end{array}$ & $\begin{array}{l}250 \\
360 \\
290 \\
120\end{array}$ & $\begin{array}{l}<.01 \\
<.01 \\
-- \\
--\end{array}$ & $\begin{array}{l}-- \\
<10 \\
<10\end{array}$ & $\begin{array}{r}110 \\
60 \\
350 \\
71\end{array}$ \\
\hline
\end{tabular}


Downstream increases in heavy-metals concentration along the river are discernible despite the variability within each site. For example, the highest concentrations of copper, lead, and zinc were downstream of river mile 3.0 ( fig. 5), in the most heavily developed area. Ir on and manganese exhibit no trends, however. (See fig. 5.)

Dividing the mean metal concentrations in sediments from below site 460 , just above the Yonkers water-treatment plant, by the mean concentrations of sediments from site 460 and above gave a ratio of 4.0 for copper, 3.8 for lead, and 3.9 for $z$ inc. The ratios for iron and manganese were both 0.9 .

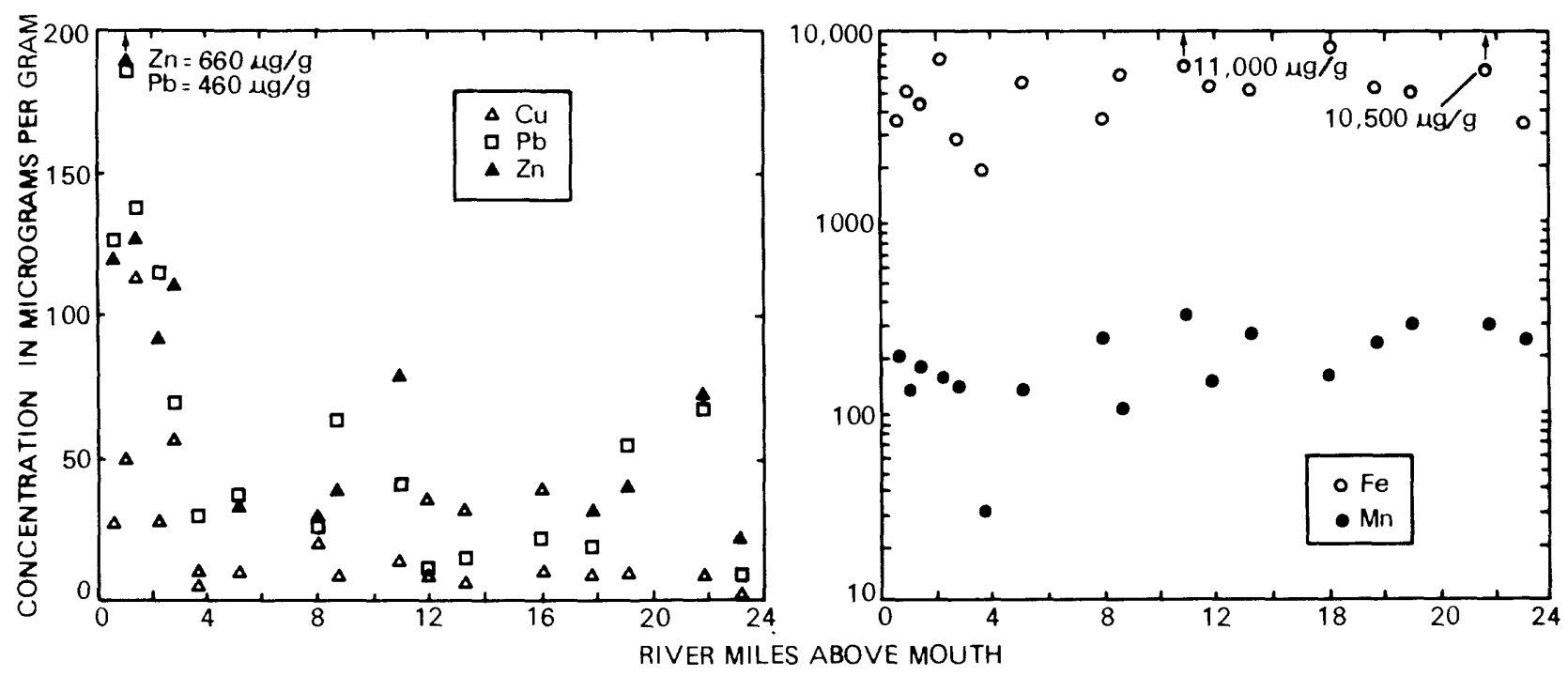

Figure 5.--Heavy-metal concentrations in 1,000- to 2,000-um bottom sediment in the Saw Mill River.

Left: Copper, lead, and zine. Right: Iron and manganese.

Location of metal sources.--The statistical distribution of heavy-metal concentrations in the bottom sediments can provide clues as to the sources of the metals. If a metal is derived solely from a geological or other natural source, its concentration in the bottom sediments will follow either normal or log-normal frequency distribution (Davies, 1980). The metals investigated here can be assumed to have at least one natural source within the drainage basin. Further, if only one source of the metal is acting throughout the entire basin, concentrations of the metal in the bottom sediments will belong to one statistical population and will be $r$ andomly distributed throughout the basin. If some concentrations are anomalously high, however, they may belong to a different statistical population, which may suggest an additional source within the basin, as Rickert and others (1977) demonstrated.

Statistical analyses were performed to determine whether the higher copper, lead, and zinc concentrations in the downstream reaches of the river were indicative of additional sources. The iron and manganese values were analyzed for comparison. Again, the sampling sites were divided into two 
groups. The five sites below river mile 3.0, which were expected to contain contaminated sediments, form the downstream group, and the 15 sites at and above river mile 3.7 form the upstream group. Because the copper concentration at site 460 , the lowe rmost of the upstream group, was below the detection limit of $10 \mu \mathrm{g} / \mathrm{g}$, a value of $9 \mu \mathrm{g} / \mathrm{g}$ was substituted. Also, the anomalously high copper value of $340 \mathrm{\mu g} / \mathrm{g}$ for site 495 , in the downstream group, was suspected to represent an analytical error and was eliminated from the analysis. These adjustments present the "worst case" for distinguishing between upstream and downstream differences in copper concentrations. That is, the adjustments result in closer mean copper values and decrease the variance within each group. Consequently, the two copper groups are more similar than if the $340-\mu \mathrm{g} / \mathrm{g}$ value had been retained and if a value of $5 \mathrm{\mu g} / \mathrm{g}$ had been used for the value below the detection limit.

Most of the copper, lead, zinc, iron, and manganase groups, both upstream and downstream, fit log-normal distributions better than normal distributions. The exceptions are the upstrean iron and manganese groups, but in both of these, the difference between the goodness-of-fit to normal distributions and to log-normal distributions is slight. Thus, all groups were treated as $10 \mathrm{~g}-$ normal distributions, and 1 og transforms of the analyses were used in the subsequent statistical tests.

If the means or variances of the upstream and downstream concentrations of a given metal are significantly different, two or more sources can be assumed. The F-test was used to compare variances, and the t-test was used to compare means. At the $\alpha=0.01$ level of significance (the 99-percent confidence level), the variances of the upstream concentrations of the five metals do not differ from the downstream variances. The means of the upstream and downstream concentrations of copper, lead, and $z$ inc are different, however, at the $\alpha=0.01$ level of significance. That is, one $c$ an be $99-$ percent confident that the means are different and, presumably, that two or more sources are contributing each of these three metals. At the $\alpha=0.10$ level of significance, neither the means of iron nor of manganese differ from upstream to downstream. In other words, no more than one significant source of iron or manganese is indicated to be supplying these metals to the riverbottom sediments.

Correlation coefficients between all possible paired combinations of copper, iron, lead, manganese, and zinc in both upstream and downstream groups of sites are presented in table 8. Coefficients for the upstream group are to the right of the diagonal, and those for the downstream group to the left. The upstream sites show significant correlations between iron and manganese, iron and $z i n c$, and manganese and $z$ inc. The downstream sites show significant correlation between lead and iron, lead and manganese, lead and zinc, and iron and manganese. The correlation of iron with manganese in both upstream and downstream sediments suggests that the two metals originate primarily from natural sources that supply the metals at about the same rate throughout the basin, and that the concentrations of neither are significantly affected by secondary sources. In contrast, the disparity between upstream and downstream correlations of lead and zinc with other metals suggest that other sources of these two metals are operating in different parts of the basin. 
Table 8.--Correlation coefficients of heavy metals in upstream and downstream bottom sediments from the Saw Mill River and tributaries, 1981-82.

[Coefficients for sediments from upstream of river mile 3.0 are right of diagonal; coefficients for sediments from downstream of river mile 3.0 are left of diagonal.]

\begin{tabular}{cccccc}
\hline & $\mathrm{Cu}$ & $\mathrm{Fe}$ & $\mathrm{Pb}$ & $\mathrm{Mn}$ & $\mathrm{Zn}$ \\
\hline $\mathrm{Cu}^{1}$ & -- & 0.329 & 0.238 & 0.119 & 0.338 \\
$\mathrm{Fe}$ & 0.050 & -- & 0.346 & $0.473 *$ & $0.877 \dagger$ \\
$\mathrm{Pb}$ & 0.348 & $0.528 * *$ & -- & 0.164 & 0.262 \\
$\mathrm{Mn}$ & 0.154 & $0.848 \dagger$ & $0.495 * *$ & -- & $0.500 *$ \\
$\mathrm{Zn}$ & 0.247 & 0.133 & $0.675 \dagger$ & 0.151 & -- \\
\hline
\end{tabular}

1 Data in table 10; calculated without using the $340 \mu \mathrm{g} / \mathrm{g} \mathrm{Cu}$ for site 495.

** Statistical significance of $\alpha<0.10$

* Statistical significance of $\alpha<0.05$

$\dagger$ Statistical significance of $\alpha<0.01$

Soils

Soil analyses for acid-leachable heavy metals are listed in table 9. Soils from sites $320,450,470,495,501$, and 503, all of which were subject to runoff from roads, parking areas, or industrial areas, had generally higher concentrations of copper, lead, and $z$ inc than soils from the other four sites. Like the river-bottom sediments, soils from the lower four sites contained the highest concentrations of copper, lead, and zinc; this trend did not hold for iron or manganese. The high lead concentrations at site 501 cannot be explained.

In general, heavy-metal concentrations in the soils were comparable to metal concentrations in the river-bottom sediments. (See tables 7 and 9.) Therefore, the heavy-metal chemistry of the bottom sediments could result largely from the direct transport of soil particles into the river. Bottom sediments in the downstream sites had higher copper and zinc concentrations than soils from the same sites, however, which suggests thay these metals are being contributed from sources other than soils. 
Table 9.--Heavy-metal concentrations in soils from the Saw Mill River basin, 1981.

[Analyses by the U.S. Geological Survey. Concentrationsin micrograms per gram of soil; Concentrations are of acidleachable metals, not total concentrations. Site locations are shown in fig. 1]

\begin{tabular}{|c|c|c|c|c|c|c|}
\hline \multirow{2}{*}{$\begin{array}{l}\text { Site- } \\
\text { identi- } \\
\text { fication } \\
\text { number }\end{array}$} & \multirow{2}{*}{$\begin{array}{l}\text { Sample } \\
\text { type }^{2}\end{array}$} & \multicolumn{5}{|c|}{ Concentrations } \\
\hline & & $\mathrm{Cu}$ & $\mathrm{Fe}$ & $\mathrm{Pb}$ & $\mathrm{Mn}$ & $\mathrm{Zn}$ \\
\hline 320 & whole & 18 & 8,300 & 170 & 380 & 100 \\
\hline \multirow[t]{2}{*}{410} & whole & 26 & 6,600 & 40 & 220 & 26 \\
\hline & fraction & 14 & 4,300 & 20 & 120 & 15 \\
\hline 415 & fraction & 10 & 4,400 & 50 & 270 & 47 \\
\hline 440 & fraction & 18 & 4,500 & 50 & 420 & 42 \\
\hline \multirow[t]{2}{*}{450} & whole & 32 & 5,700 & 120 & 250 & 110 \\
\hline & fraction & 21 & 4,000 & 120 & 130 & 39 \\
\hline \multirow[t]{2}{*}{460} & whole & 17 & 7,100 & 20 & 310 & 31 \\
\hline & fraction & 10 & 5,600 & 10 & 140 & 21 \\
\hline \multirow[t]{2}{*}{470} & whole & 42 & 5,300 & 180 & 170 & 110 \\
\hline & fraction & 20 & 3,900 & 90 & 91 & 60 \\
\hline \multirow[t]{2}{*}{495} & whole & 40 & 3,600 & 280 & 200 & 110 \\
\hline & fraction & 25 & 4,200 & 210 & 140 & 83 \\
\hline \multirow[t]{2}{*}{501} & whole & 52 & 4,500 & 1,100 & 200 & 250 \\
\hline & fraction & 20 & 5,200 & 1,900 & 110 & 280 \\
\hline 503 & fraction & 96 & 3,900 & 210 & 160 & 160 \\
\hline
\end{tabular}

1 Soil sampling sites are identified by the closest river sampling sites; all soil samples were collected within $1,000 \mathrm{ft}$ of the river site and most within $200 \mathrm{ft}$.

2 Whole samples include all soil materials $<2,000 \mu \mathrm{m}$; fraction samples include only $1,000-2,000-\mu m$ grains. 
Most ceramic tiles had developed brown to black coatings of iron and manganese oxides within 6 weeks after they were emplaced in the river in April 1982. Tiles that became buried by sediment soon after emplacement formed little or no coating, however, and tiles that became buried after coatings had formed exhibited a blotchy appearance that suggests partial dissolution of the coating during burial. Only tiles found above the sediment line at the time of collection were removed for analysis. The extent and frequency of burial varied among sites and was a function of the sediment composition of the streambed.

Periphyton coatings developed on the tiles within a few weeks after they were emplaced. Algal growth increased through the summer and began to decrease in the fall; some periphyton remained into the winter. Periphyton on tiles at the two lowermost sites ( 495 and 503) consisted solely of slimes and was markedly less abundant than at sites upriver, which may be a reflection of differences in water quality.

Analyses of the ceramic-tile coatings are presented in table 10. Seven sets of analyses are given for the four upstream sites; fewer analyses are available for the lower three sites. Analyses of the original tiles and a replacement set are presented for site 495; analyses of control tiles kept in the laboratory are included.

Ceramic tiles have an advantage over coarse bottom sediments in that they more readily collect detectable and distinguishable quantities of the minor metals such as cadmium and cobalt. (Compare tables 7 and 10.)

Significant chemical differences are apparent between coatings formed on the tiles and those formed on the bottom sediments. The most notable difference is the ratio of iron to manganese. In the 1,000- to 2,000- $\mu \mathrm{m}$ bottom sediments, iron concentrations are at least 25 times greater than the manganese concentrations, whereas on the tiles, the manganese concentration greatly exceeds that of iron. This observation agrees with findings by Carpenter and others (1975), who found iron-to-manganese ratios on boulder coatings to be much lower than those on bottom sediments from the same location. Carpenter and Hayes (1980) later found iron-to-manganese ratios of coatings on submerged tiles to be similar to those in boulder coatings in the same stream. The ratios of other metals in both tile and boulder coatings in that study also differed significantly from those of leachable metals in bottom sediments.

The tile analyses indicate that, after a rapid buildup of metals during the first 6 weeks, the accretion rate declined and varied with time. Metal concentrations at some sites decreased between tile collections. Carpenter and Hayes (1980) noted similar variations with time. These variations could result from several factors; for example, intermittent burial of tiles between collection trips could reduce the thickness or change the character of the coatings, and variations in the rate of periphyton growth on the tiles or abrasion of the coatings during high flows could also affect the concen-. trations. Despite the variability, however, the trend of the metal concentrations was upward with time. 
Table 10.--Heavy-metal concentrations on ceramic tiles emplaced on bottom of the Saw Mill River.

[Analyses by U.S. Geological Survey. Concentrations in $\mu \mathrm{g} / \mathrm{cm}^{2}$ of tile surface. Site locations are shown in $f$ ig. 1.]

\begin{tabular}{|c|c|c|c|c|c|c|c|c|c|c|c|}
\hline $\begin{array}{c}\text { Site } \\
\text { Number } \\
\end{array}$ & $\begin{array}{c}\text { Date } \\
\text { collected } \\
\end{array}$ & $\begin{array}{l}\text { No. of } \\
\text { days in } \\
\text { place }\end{array}$ & $\mathrm{Cd}$ & $\mathrm{Cr}$ & Co & $\mathrm{Cu}$ & $\mathrm{Fe}$ & $\mathrm{Pb}$ & $\mathrm{Mn}$ & N1 & $\mathrm{Zn}$ \\
\hline \multirow[t]{7}{*}{320} & $06-02-82$ & 42 & 4 & 4 & $<4$ & 50 & 1,800 & 47 & -- & 18 & 110 \\
\hline & $07-19-82$ & 89 & 7 & -- & 14 & - & 2,700 & 110 & 14,000 & 61 & 430 \\
\hline & $08-24-82$ & 125 & 11 & $<4$ & 25 & 54 & 3,100 & 120 & 16,000 & 61 & 540 \\
\hline & $09-29-82$ & 161 & 7 & 14 & 22 & 79 & 4,000 & 220 & 14,000 & 65 & 610 \\
\hline & $11-09-82$ & 202 & 4 & 11 & 25 & 68 & 4,300 & 210 & 13,000 & 61 & 580 \\
\hline & $\mid 2-21-82$ & 244 & 18 & 7 & 50 & 58 & 2,800 & 180 & 12,000 & 100 & 400 \\
\hline & $02-01-83$ & 286 & 4 & 4 & 54 & 220 & 5,000 & 260 & 19,000 & 83 & 680 \\
\hline \multirow[t]{7}{*}{410} & $06-02-82$ & 42 & 4 & -- & 11 & 54 & 1,900 & 54 & 11,000 & 25 & 220 \\
\hline & $07-19-82$ & 89 & 11 & 4 & 11 & 54 & 2,000 & 120 & 13,000 & 47 & 290 \\
\hline & $08-24-82$ & 125 & 18 & $<4$ & 43 & 110 & 2,300 & 200 & 22,000 & 100 & 680 \\
\hline & $09-29-82$ & 161 & 7 & 11 & 32 & 68 & 3,200 & 300 & 30,000 & 120 & 970 \\
\hline & $11-09-82$ & 202 & 7 & 11 & 43 & 83 & 5,000 & 330 & 30,000 & 140 & 900 \\
\hline & $12-21-82$ & 244 & 7 & 4 & 76 & 86 & 4,300 & 470 & 40,000 & 210 & 1,100 \\
\hline & $02-01-83$ & 286 & 14 & 4 & 130 & 200 & 5,800 & 500 & 61,000 & 500 & 1,700 \\
\hline \multirow[t]{7}{*}{443} & $06-02-82$ & 42 & 4 & -- & 14 & 47 & 4,000 & 97 & 25,000 & 29 & 400 \\
\hline & $07-19-82$ & 89 & 4 & 14 & 32 & 58 & 4,900 & 160 & 56,000 & 61 & 340 \\
\hline & $08-24-82$ & 125 & 7 & $<4$ & 36 & 65 & 3,600 & 130 & 40,000 & 61 & 360 \\
\hline & $09-29-82$ & 161 & 7 & 11 & 22 & 79 & 5,400 & 170 & 27,000 & 94 & 680 \\
\hline & $11-09-82$ & 202 & $<4$ & 11 & 32 & 79 & 9,400 & 170 & 36,000 & 94 & 610 \\
\hline & $12-21-82$ & 244 & 7 & 4 & 50 & 79 & 6,500 & 120 & 36,000 & 160 & 540 \\
\hline & $02-01-83$ & 286 & 4 & 4 & 65 & 200 & 9,700 & 190 & 47,000 & 140 & 830 \\
\hline \multirow[t]{7}{*}{450} & $06-02-82$ & 42 & 18 & 11 & 47 & 90 & 4,700 & 130 & 54,000 & 65 & 500 \\
\hline & $07-19-82$ & 89 & 11 & 14 & 61 & 100 & 6,100 & 240 & 65,000 & 160 & 950 \\
\hline & $08-24-82$ & 125 & 11 & $<4$ & 40 & 110 & 4,000 & 220 & 47,000 & 130 & 1,100 \\
\hline & $09-29-82$ & 161 & 4 & 18 & 25 & 58 & 5,800 & 150 & 36,000 & 83 & 470 \\
\hline & $11-09-82$ & .202 & $<4$ & 11 & 32 & 83 & 6,500 & 230 & 29,000 & 100 & 860 \\
\hline & $12-21-82$ & 244 & 10 & $<4$ & 72 & 140 & 5,400 & 430 & 47,000 & 260 & 1,500 \\
\hline & $02-01-83$ & 286 & 7 & 7 & 83 & 270 & 9,000 & 290 & 65,000 & 500 & 2,300 \\
\hline \multirow[t]{4}{*}{470} & $06-23-82$ & 63 & 11 & 4 & 72 & 180 & 5,800 & 220 & 79,000 & 160 & 1,000 \\
\hline & $07-19-82$ & 89 & 22 & 18 & 68 & 110 & 5,800 & 260 & 155,000 & 230 & 1,200 \\
\hline & $08-24-82$ & 125 & 25 & 7 & 61 & 190 & 6,100 & 360 & 137,000 & 310 & 1,700 \\
\hline & $09-29-82$ & 161 & 32 & 11 & 58 & 210 & 7,200 & 310 & 137,000 & 360 & 2,400 \\
\hline \multirow[t]{5}{*}{4952} & $06-23-82$ & 63 & 7 & $<4$ & 65 & 290 & 8,300 & 170 & 36,000 & 110 & 1,330 \\
\hline & $07-19-82$ & 89 & 80 & 4 & 36 & 100 & 8,100 & 240 & 76,000 & 100 & 1,900 \\
\hline & $11-09-82$ & 41 & $<4$ & 11 & 4 & 36 & 3,600 & 94 & -- & $<4$ & 140 \\
\hline & $12-21-82$ & 83 & 10 & $<4$ & 43 & 86 & 7,200 & 140 & 13,000 & 27 & 610 \\
\hline & $02-01-83$ & 125 & 7 & 11 & 72 & 190 & 9,700 & 230 & 32,000 & 65 & 1,300 \\
\hline \multirow[t]{6}{*}{503} & $07-19-82$ & 26 & 7 & 11 & 40 & 110 & 4,500 & 160 & 100,000 & 100 & 2,000 \\
\hline & $08-24-82$ & 62 & 29 & 7 & 76 & 330 & 11,000 & 650 & 140,000 & 310 & 4,000 \\
\hline & $09-29-82$ & 98 & 36 & 22 & 140 & 360 & 22,000 & 650 & 130,000 & 580 & 6,800 \\
\hline & $11-09-82$ & 139 & 50 & 18 & 280 & 610 & 40,000 & 1,200 & 400,000 & 680 & $i 1,000$ \\
\hline & $12-21-82$ & 181 & 43 & 40 & 180 & - & 140,000 & 1,200 & 220,000 & 540 & 8,600 \\
\hline & $02-01-83$ & 223 & 36 & -- & 190 & 540 & 150,000 & 1,300 & 280,000 & 650 & 9,700 \\
\hline Laboratory & $06-02-82$ & 42 & $<4$ & -- & $<4$ & -- & 500 & 30 & $<36$ & 20 & 72 \\
\hline \multirow[t]{6}{*}{ tiles } & $07-19-82$ & 89 & $<4$ & -- & 10 & 20 & 180 & 20 & 72 & 4 & 36 \\
\hline & $08-24-82$ & 125 & 7 & $<4$ & 10 & 30 & 470 & 10 & 36 & 7 & 72 \\
\hline & $09-29-82$ & 161 & 4 & 7 & $<4$ & 20 & 320 & 30 & $<36$ & 7 & 72 \\
\hline & $11-09-82$ & 202 & $<4$ & 10 & 1 & 10 & 760 & 30 & $<36$ & $<4$ & 110 \\
\hline & $12-21-82$ & 244 & 4 & $<4$ & -- & 30 & 360 & 40 & $<36$ & 20 & 72 \\
\hline & $02-01-83$ & 286 & 4 & $<4$ & 4 & 10 & 250 & 25 & $<36$ & 4 & 72 \\
\hline
\end{tabular}

1 Tile sets were emplaced originally at all sites on 04-21-82. Tile sets were lost from sites 470,495 , and 503 during the study. Tiles were replaced at sites 495 and 503 on $09-29-82$ and 06-23-82, respectively.

2 First two sets of analyses represent original tile set; last three sets of analyses represent replacement t1les emplaced on 09-29-82. 
Metal concentrations on tiles from the three lowermost sites $(470,495$, and 503) were appreciably higher than on tiles that had been in place for a comparable period further upstream. (See table 10.) Plots of the metal concentrations in relation to river miles from sites 320 through 503 on two collection dates are shown in figure 6; site 495 is not included in these plots because the original tile set was lost early in the study. Iron and manganese concentrations on tiles from the lower sites we re appreciably higher than on tiles from upstream sites, unlike the bottom sediment samples, which did not show downstream enrichment of iron and manganese. Chromium values at al1 sites but 503 were similar to those of the laboratory control tiles. Concentrations of all metals at site 443, which is immediately downstream from an impoundment, were low in relation to sites on either side. The setting of the site may be responsible for the lower concentrations, but no mechanism for the difference is offered.

The chemistry of the tile coatings must be interpreted with caution because few studies relating stream-water quality to heavy-metal deposition on artificial substrates have been done. Carpenter and Hayes (1978) found a correlation between quantity of heavy metals entering a stream and the concentrations of the metals deposited on ceramic tiles at specified distances downstream. Cerling and Turner (1982) found that coatings that formed on glass plates emplaced in a stream were related to the metal concentrations, the $\mathrm{pH}$, and the oxidation potential of the water. Results of the above seem to support indications that higher heavy-metal concentrations on tiles at downstream sites reflect a downstream deterioration in water quality.

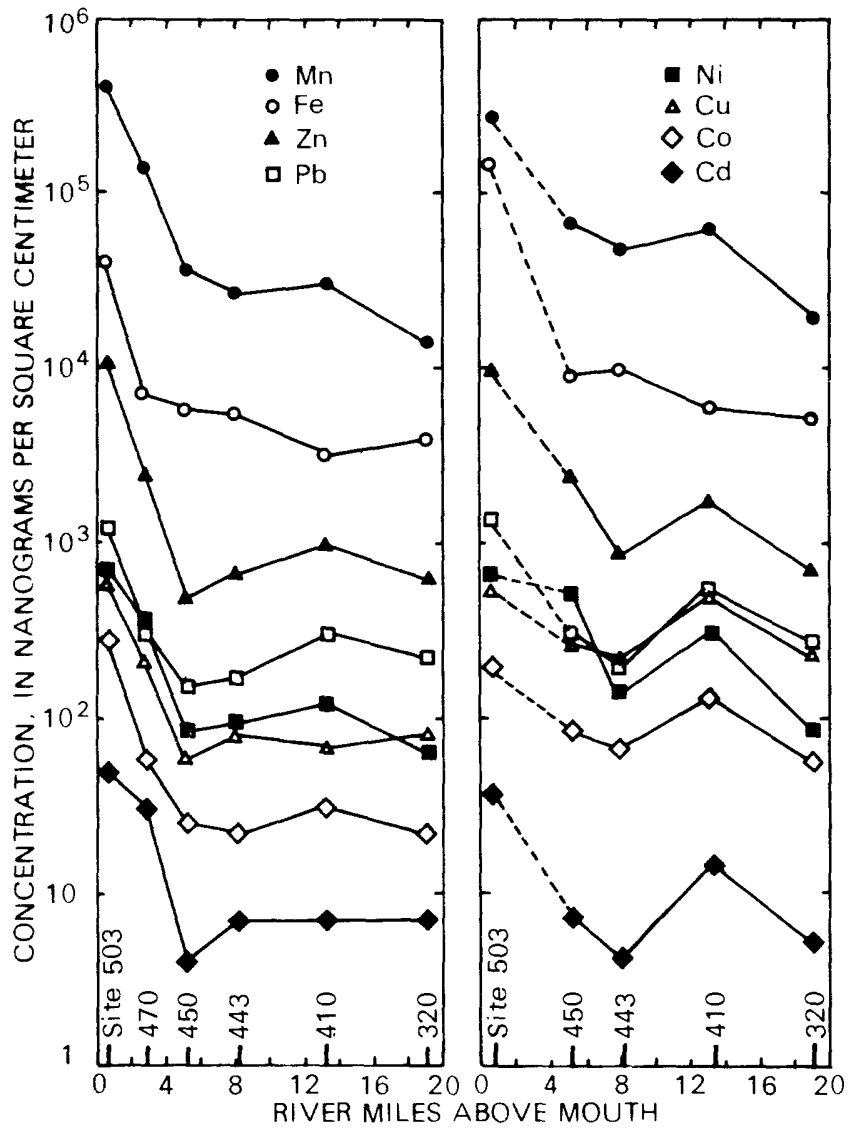

\section{Figure 6.}

Concentrations of heavy metals deposited on ceramic tiles emplaced in the saw Mill River. 


\title{
Organic Compounds
}

\author{
River water
}

Few organic compounds were detected in river-water samples. Volatile organic compounds were detected in all samples collected in February and August 1981, but none were detected in samples collected in August 1982. Results are given in table 11. The volatile organic compounds detected in this study were solvents used principally as metal cleaners, degreasers, and dry-cleaning agents. Volatile organic compounds are difficult to sample and analyze, and only a small number of samples were analyzed; thus the results reported herein should not necessarily be considered representative of the river.

Water samples collected in April and August 1982 at sites $320,420,460$, and 503 were analyzed for acid- and base/neutral-extractable organic compounds and organochlorine and organophosphorous compounds. The only sample to contain any of these compounds above their analytical detection 1 imits ( $t a b l e s 2$ and 4) was the August sample from site 503, in which the total gross PCB concentration was $0.1 \mu \mathrm{g} / \mathrm{L}$.

Table 11.-Concentrations of volatile organic compounds in the Saw Mill River, 1981-82.

[Analyses of the U.S. Geological Survey. N.D., none detected at minimum detection 1 imit of 1.0 microgram per liter; see table 2 for a complete 1 ist of compounds on the analys is 1 ist. Site locations are shown in fig. 1.]

\begin{tabular}{|c|c|c|c|}
\hline $\begin{array}{l}\text { Site- } \\
\text { identi- } \\
\text { fication } \\
\text { number }\end{array}$ & Date & Compound (s) detected & $\begin{array}{c}\text { Concentration } \\
(\mu \mathrm{g} / \mathrm{L})\end{array}$ \\
\hline 320 & $\begin{array}{l}02-10-81 \\
08-17-82\end{array}$ & $\begin{array}{c}\text { Tetrach loroe thy lene } \\
\text { N.D. }\end{array}$ & 2.0 \\
\hline 420 & $08-17-82$ & N. D. & -- \\
\hline 460 & $\begin{array}{l}02-10-81 \\
08-12-81 \\
08-17-82\end{array}$ & $\begin{array}{l}\text { 1,2-trans-Di chl oroethylene } \\
\text { Tr ich loroethyl ene } \\
\text { 1,2-trans-Dichloroethylene } \\
\text { Trichloroethylene } \\
\text { N.D. }\end{array}$ & $\begin{array}{r}2.0 \\
10.0 \\
8.0 \\
20.0 \\
--\end{array}$ \\
\hline 495 & $08-12-81$ & $\begin{array}{l}1,2-\operatorname{trans}-\mathrm{D} i \mathrm{ch} 1 \text { oroethy } 1 \text { ene } \\
1,1,1-\operatorname{Tr} \text { ichloroethane }\end{array}$ & $\begin{array}{r}8.0 \\
30.0\end{array}$ \\
\hline 503 & $\begin{array}{l}02-10-81 \\
08-17-82\end{array}$ & $\begin{array}{c}\text { Trich loroethylene } \\
\text { N.D. }\end{array}$ & $\begin{aligned} 2.0 \\
--\end{aligned}$ \\
\hline
\end{tabular}


Samples from 11 sites were collected in September 1981 and analyzed for total phenols. Eight of the sites $(310,320,390,410,440,443,450,460)$ showed concentrations below the analytical detection 1 imit of $1 \mathrm{\mu g} / \mathrm{L}$; the other three (sites 420, 495, and 503) had concentrations of 2, 4, and $1 \mu \mathrm{g} / \mathrm{L}$, respectively. Total phenols include a variety of organic compounds, both natural and synthetic. Chlorinated phenols can cause odors in domestic water supplies; they may form when phenols entering a water-treatment plant are chlorinated in the final treatment process. To avoid odors, a water-quality criterion of $1 \mu \mathrm{g} / \mathrm{L}$ total phenols has been established by the U.S. Environmental Protection Agency (1977) for domestic water supplies.

Total cyanide was determined on two samples collected at sites 440 and 460 in August 1981; neither was above the detection 1 imit of $0.01 \mathrm{\mu g} / \mathrm{L}$.

\section{Bottom Sediments}

Concentrations of organochilorine compunus detected in whole bottom sediments are summarized in table 12; most of the compounds on the analysis list were not present above the analytical detection 1 imits. (Compare tables 4 and 12). No organophosphorous compounds were detected.

Pesticides and PCB's.--The pesticide DDT and its metabolites DDD and DDE are present in bottom sediments throughout the basin and, as a group, follow no apparent spatial trend ( $f$ ig. 7). DDD concentrations may be higher downstream of river mile 6.0, however ( $t$ able 12). The pesticides chlordane and dieldrin are both present at all but the uppermost site and, as with DDT, they follow no apparent spatial trend. Chlordane was the most abundant pesticide in the river-bottom sediments. Heptachlor expoxide, a metabolite of the pesticide heptachlor, was detected at only one site.
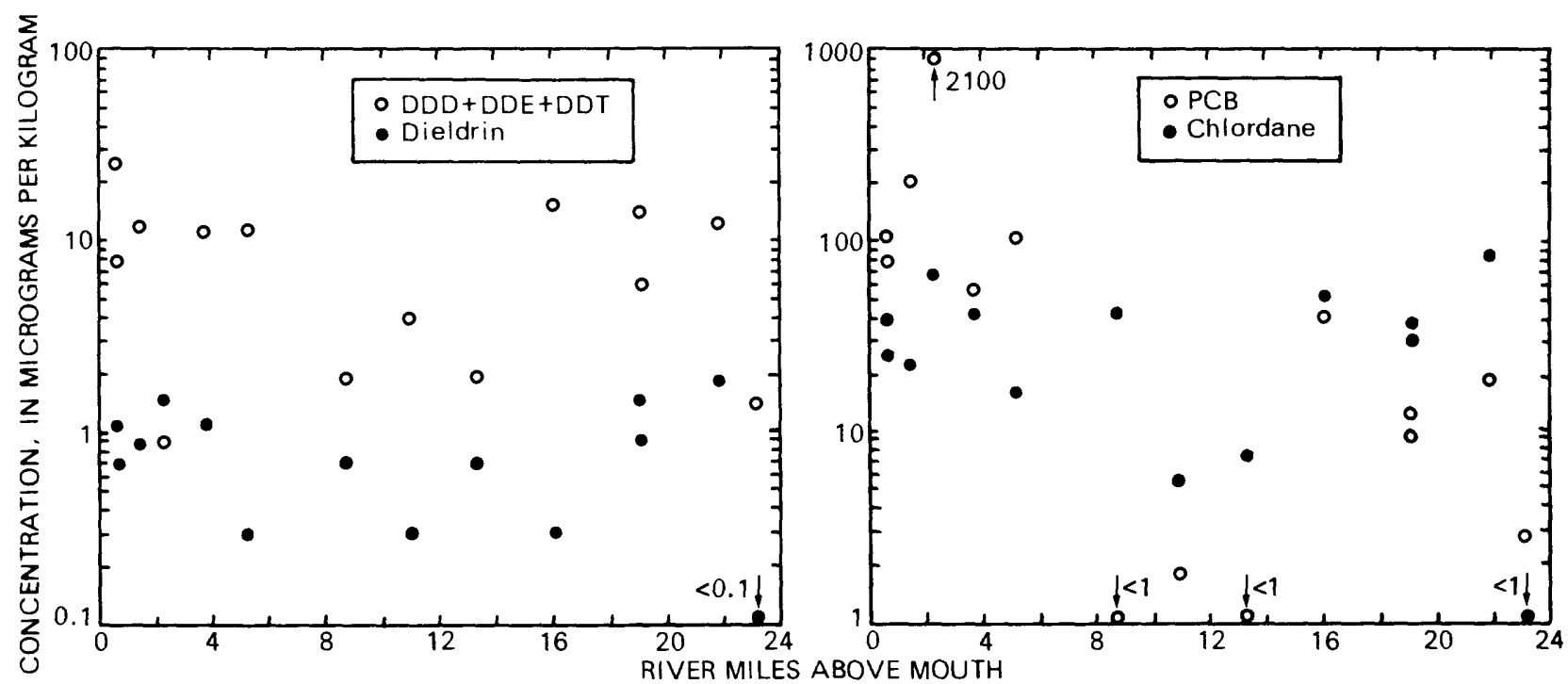

Figure 7.--Plots showing chlorinated hydrocarbon concentrations in bottom sediments in the Saw Mill River.

A. Dieldrin and DDD + DDE + DDT. B. Chlordane and PCB. 
PCBs, unlike the pesticides, exhibit a pronounced trend. The six highest $P C B$ concentrations, and the only concentrations above $50 \mu \mathrm{g} / \mathrm{kg}$, were found below river mile 6.0. (See fig. 7.)

In 1976, bottom sediments from four sites on the Saw Mil1 River were analyzed by the U.S. Geological Survey for organochlorine compounds (Archer and Turk, 1977). The 1976 samples were collected at or near sites 415, 420, 460, and 495 of this study. Results of the 1976 analyses are 1 isted in table 13.

\section{Table 12.--Concentrations of organochlorinecompounds in bottom sediments from the Saw Mill River, 1981.}

[Analyses by the Geological Survey. Concentrations in $\mu \mathrm{g} / \mathrm{kg}$; concentrations of organophosphorous and other organochlorine compounds were below minimum detection limits; see table 4 for a complete list of compounds on the analysis list. Site locations as shown in $\mathrm{fig} .1$.

\begin{tabular}{|c|c|c|c|c|c|c|c|c|}
\hline \multirow{2}{*}{$\begin{array}{l}\text { Site- } \\
\text { identi- } \\
\text { fication } \\
\text { number }\end{array}$} & \multirow[b]{2}{*}{ Date } & \multicolumn{7}{|c|}{ Concentrations } \\
\hline & & $\begin{array}{l}\text { Ch1or- } \\
\text { dane }\end{array}$ & DDD & DDE & $\mathrm{DDT}$ & $\begin{array}{l}\text { Die1- } \\
\text { drin }\end{array}$ & $\begin{array}{c}\text { Gros s } \\
\text { PCB }\end{array}$ & $\begin{array}{l}\text { Heptachlor } \\
\text { epoxide }\end{array}$ \\
\hline 308 & $11-17-81$ & $<1.0$ & 0.4 & 0.7 & 0.3 & $<0.1$ & 3 & $<0.1$ \\
\hline 310 & $08-12-81$ & 91 & $<.1$ & 12 & $<.1$ & 1.8 & 20 & $<.1$ \\
\hline \multirow[t]{2}{*}{320} & $02-10-81$ & 38 & 1.2 & 8.4 & 4.1 & 1.4 & 10 & .4 \\
\hline & $08-12-81$ & 32 & 1.6 & $<.1$ & 4.2 & .9 & 13 & $<.1$ \\
\hline 390 & $09-02-81$ & 55 & 2.2 & 5.6 & 8.2 & .3 & 42 & $<.1$ \\
\hline 410 & $08-11-81$ & 8.0 & $<.1$ & $<.1$ & 1.9 & .7 & $<.1$ & $<.1$ \\
\hline 420 & $08-11-81$ & 6.0 & 2.0 & .6 & 1.4 & .3 & 19 & $<.1$ \\
\hline 440 & $08-12-81$ & 43 & $<.1$ & $<.1$ & 1.9 & .7 & $<.1$ & $<.1$ \\
\hline 450 & $09-01-81$ & 17 & 6.2 & 1.6 & 3.2 & .3 & 110 & $<.1$ \\
\hline 460 & $08-12-81$ & 44 & 9.2 & .6 & 1.2 & 1.1 & 58 & $<.1$ \\
\hline 475 & $08-12-81$ & 69 & $<.1$ & .9 & $<.1$ & 1.5 & 2,100 & $<.1$ \\
\hline 495 & $08-12-81$ & 23 & 9.2 & $<.1$ & 2.6 & .9 & 210 & $<.1$ \\
\hline 503 & $\begin{array}{l}02-10-81 \\
08-12-81\end{array}$ & $\begin{array}{l}41 \\
27\end{array}$ & 11 & $\begin{array}{l}<.1 \\
<.1\end{array}$ & 14 & 1.1 & $\begin{array}{r}84 \\
110\end{array}$ & $<.1$ \\
\hline & 01201 & & 0.3 & 1 & 1.1 & .7 & 110 & $<.1$ \\
\hline
\end{tabular}


Because analyses of bottom sediments yield only semiquantitative results, it is imposible to compare data from 1976 to data from this study quantitatively. Also, the comparisons that $c$ an be made are limited by the small number of analyses from 1976. Several observations are noteworthy, however. First, al1 organochlorine compounds detected in 1976 were detected in this study, and vice versa. Second, the highest concentrations of organochlorine compounds in both 1976 and in this study 1981 were found at or downstream from site 460.

Table 13.--Concentrations of organochlorine compounds in bottom sediments from the saw Mill River, 1976.

[Analyses by U.S. Geological Survey. Concentrations in $\mu \mathrm{g} / \mathrm{kg}$; source: Archer and Turk, 1977. Site locations are shown in fig. 1. Dashes indicate concentrations below detection limit.]

\begin{tabular}{lccccccccc}
\hline $\begin{array}{l}\text { Site } \\
\text { identi- } \\
\text { fication }\end{array}$ & Date & $\begin{array}{l}\text { Chlor- } \\
\text { dane }\end{array}$ & DDD & DDE & DDT & $\begin{array}{l}\text { Die1- } \\
\text { drin }\end{array}$ & $\begin{array}{c}\text { Gross } \\
\text { PCB }\end{array}$ & $\begin{array}{l}\text { Heptachlor } \\
\text { epoxide }\end{array}$ \\
\hline 415 & $08-31-76$ & 11 & 1.4 & -- & 1.3 & -- & -- & -- \\
420 & $08-31-76$ & 10 & 2.7 & 0.7 & 3.5 & 0.7 & 38 & 0.1 \\
460 & $08-31-76$ & 55 & 12 & -- & -- & -- & 42 & -- \\
495 & $08-31-76$ & 99 & 24 & -- & 18 & -- & 720 & -- \\
& $11-17-76$ & 110 & 41 & 7.6 & 23 & 5.7 & 1,300 & -- \\
\hline
\end{tabular}

1 Sites identified by number of the closest site in this study.

Acid- and base/neutral-extractable compounds.--Concentrations of acid- and base/ neutral-extractable organic compounds detected in bottom sediments are 1 isted in table 14. Concentrations of organic compounds in bottom sediments are dependent on the matrix composition of the sediment and do not simply reflect the concentration or quantity of the compound in the water column that has passed over the sediment. In general, as the organic carbon content of sediment increases, so does its ability to sorb organic contaminants (Goerlitz and Law, 1974; Means and others, 1980). Variations in sediment composition complicate comparisons among the samples, but several general observations can be made. 
Table 14.--Concentrations of acidin bottom sediments from

[Analyses by U.S. Geological Survey. Concentration in $\mu \mathrm{g} / \mathrm{kg}$. Dashes indicate not detected; detection 1 imits are dependent An approximate detection 1 imit of $20 \mathrm{\mu g} / \mathrm{kg}$ has been established

\begin{tabular}{|c|c|c|c|c|c|c|c|c|c|c|}
\hline $\begin{array}{r}\text { Site } \\
\text { no. }\end{array}$ & $\begin{array}{c}\text { Date } \\
\text { collected }\end{array}$ & 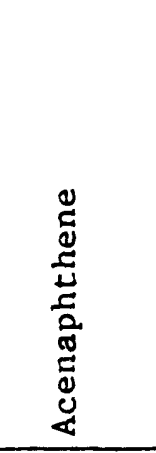 & 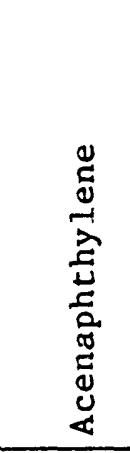 & 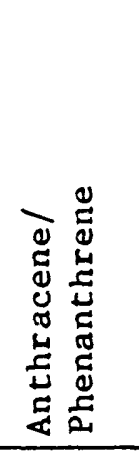 & 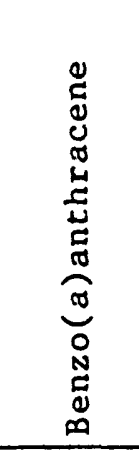 &  & 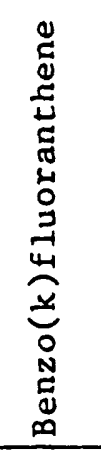 & 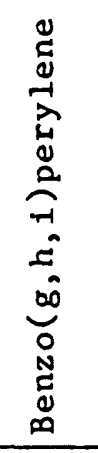 &  & 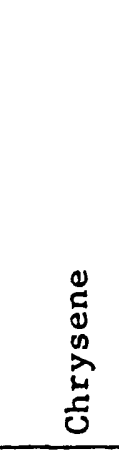 \\
\hline 320 & $\begin{array}{l}08-12-81^{1} \\
08-24-82\end{array}$ & -- & -- & $\begin{array}{l}1,900 \\
1,440\end{array}$ & 810 & 1,400 & $=$ & -- & 830 & $-\overline{640}$ \\
\hline 410 & $08-24-82$ & -- & -- & -- & -- & -- & -- & -- & -- & -- \\
\hline 420 & $\begin{array}{l}08-11-81^{1} \\
08-24-82\end{array}$ & $\begin{array}{l}-- \\
--\end{array}$ & -- & $\begin{array}{r}200 \\
1,100\end{array}$ & $\overline{--}$ & 370 & -- & $=$ & $5 \overline{70}$ & $3, \overline{--}$ \\
\hline 450 & $08-24-82$ & -- & -- & 360 & 350 & -- & 220 & 340 & -- & 290 \\
\hline 460 & $\begin{array}{l}08-11-81 \\
08-24-82\end{array}$ & -- & -- & $\begin{array}{l}65 \\
--\end{array}$ & -- & $\begin{array}{l}-- \\
--\end{array}$ & $=-$ & $=$ & $\begin{array}{l}-- \\
--\end{array}$ & $\overline{--}$ \\
\hline 470 & $08-24-82$ & -- & -- & 3,130 & 700 & 820 & -- & -- & 1,100 & 420 \\
\hline 495 & $\begin{array}{l}08-12-81 \\
08-24-82\end{array}$ & $13, \overline{0} 00$ & $6--$ & $\begin{array}{r}170 \\
6,800\end{array}$ & 1,400 & 1,700 & $=$ & 320 & 860 & 1,600 \\
\hline 503 & $\begin{array}{l}08-12-81^{1} \\
08-24-82\end{array}$ & $\begin{array}{l}-- \\
--\end{array}$ & 1,800 & $\begin{array}{r}490 \\
1,190\end{array}$ & 280 & 290 & -- & $\overline{97}$ & 290 & $\overline{170}$ \\
\hline
\end{tabular}

1 Gas-chromatograph/mass-spectrometer scans, not full analyses. 
the Sal Mizl Fiver, 1a81-32.

Site locations are shown in fig. 1.

on the matrix composition of the sediment and are variable.

by the laboratory; ND indicates not determined.]

\begin{tabular}{|c|c|c|c|c|c|c|c|c|c|c|c|c|}
\hline $\begin{array}{c}\text { Site } \\
\text { no. }\end{array}$ & 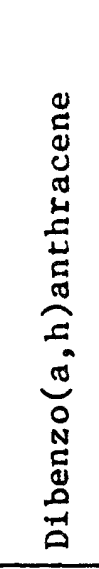 & 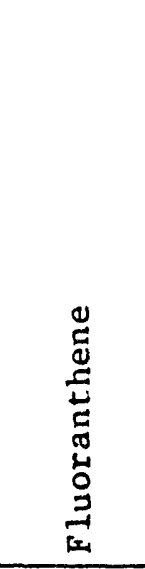 & 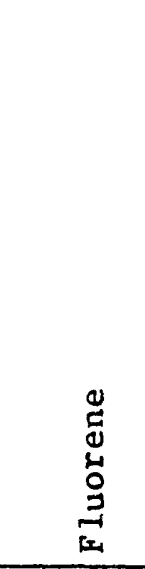 & 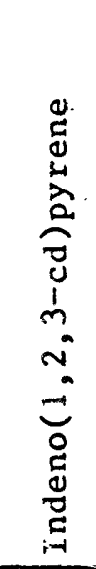 & 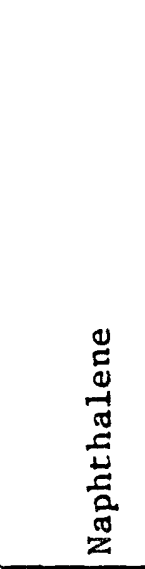 & 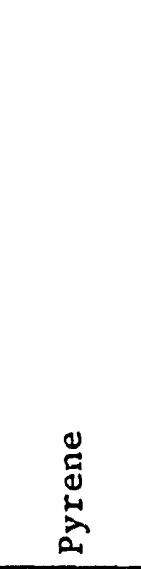 & 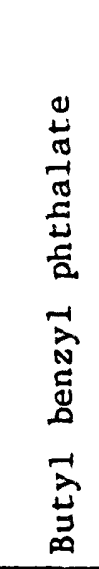 & 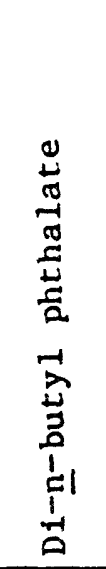 & 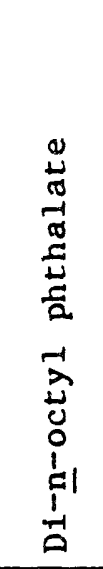 & 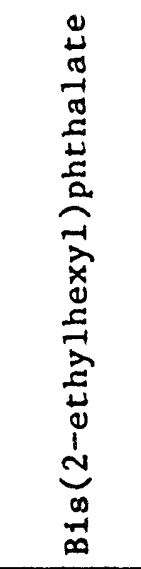 & 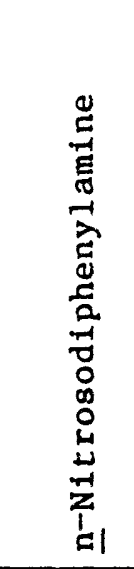 & 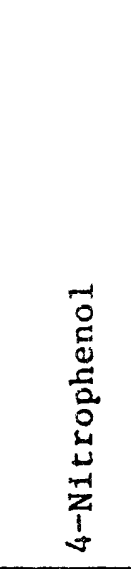 \\
\hline 320 & -- & $\begin{array}{l}1,300 \\
1,100\end{array}$ & $\begin{array}{r}240 \\
--\end{array}$ & -- & -- & $\begin{array}{l}1,200 \\
1,000\end{array}$ & -- & 260 & -- & 2,200 & -- & $\begin{array}{l}\text { ND } \\
--\end{array}$ \\
\hline 410 & -- & -- & -- & -- & -- & -- & -- & -- & -- & -- & -- & -- \\
\hline 420 & 520 & $\begin{array}{r}160 \\
1,100\end{array}$ & -- & -- & -- & $\begin{array}{r}230 \\
1,200\end{array}$ & -- & 340 & -- & 1,400 & -- & $\begin{array}{l}\text { ND } \\
--\end{array}$ \\
\hline 450 & -- & 860 & -- & 45 & -- & 850 & -- & -- & -- & -- & -- & -- \\
\hline 460 & $\begin{array}{r}8 \\
--\end{array}$ & 20 & -- & -- & -- & 110 & -- & -- & -- & -- & -- & -- \\
\hline 470 & -- & 590 & -- & -- & -- & 1,200 & -- & 380 & -- & 2,400 & -- & -- \\
\hline 495 & -- & $\begin{array}{r}165 \\
6,000\end{array}$ & 1,200 & 270 & 1,200 & $\begin{array}{r}210 \\
5,000\end{array}$ & 950 & 420 & 610 & 740 & -- & 4,200 \\
\hline 503 & -- & $\begin{array}{l}280 \\
350\end{array}$ & $\begin{array}{l}21 \\
--\end{array}$ & 100 & -- & $\begin{array}{l}320 \\
600\end{array}$ & -- & - & $-\infty$ & $-\infty$ & 1,400 & $\begin{array}{l}\text { WD } \\
-\cdots\end{array}$ \\
\hline
\end{tabular}


of the 57 compounds on the analysis list (table 2), 22 were detected in the Saw Mill River sediments. Only one acid-extractable compound, 4-nitrophenol, was detected, and it was detected at only one site (site 495). of the 21 base/neutral-extractable compounds detected, six were at only one site, and four of the six were at site 495. Six compounds were detected at five or more sites; all were polynuclear aromatic hydrocarbons.

of the 22 compounds detected in the river, 19 were at site 495 and 14 at site 503. The highest concentrations of 16 compounds were also found at either site 495 or 503 . The high concentrations of organic compounds in the 1982 sample from site 495 ( $t a b l e$ 14) may be explained in part by a high sorptive capacity of the sediment as a result of its high organic carbon concentration. The organic carbon concentration of 1,000- to 2,000- $\mu \mathrm{m}$ sediment collected at the same time as the sediment sample for organic compounds was $100 \mu \mathrm{g} / \mathrm{kg}$, much higher than at the other sites (table 17). (The $1981 \mathrm{sample}$ from site 495 was collected soon after completion of the concrete channel and may not have been fully representative of the site at later sampling times.) The higher concentrations found at site 503, however, cannot be attributed to abnormally high concentrations of organic carbon.

The only site at which none of the acid- or base/neutral-extractables were detected was site 410. The low organic carbon concentrations in sediment at that site (table 17) may be partly responsible.

The largest group of base/neutral-extractable compounds detected in the bottom sediments was polynuclear aromatic hydrocarbons (PAH's). PAH's form a diverse group of chemical compounds that are widely distributed in the environment. They occur in fossil fuels and are common combustion products of carbon-based materials such as gasoline and diesel fuel.

Phthalate esters were detected in bottom sediments from five sites (table 14). Phthalate esters, which are used in the manufacturing of plastics, are ubiquitous, and samples are often subject to contamination by these compounds during collection and in the laboratory. Because "background" levels of phthalate esters in the enviroment are not known, and because relatively few values are available from this study, it is not possible to determine the severity of phthalate contamination in the Saw Mill River or if it even exists.

Total cyanide.--The following bottom-sediment size fractions, collected in August 1981, were analyzed for total cyanide: 1,000- to 2,000- $\mu \mathrm{m}$ sediment from 13 sites, five finer sediment fractions from sites 460 and 495 , and whole sediment from sites 460 and 495. All values were below the detection limit of $0.5 \mathrm{mg} / \mathrm{kg}$. 


\section{RELATION OF RIVER QUALITY TO URBANIZATION}

Nonpoint sources of contaminants can significantly affect river quality. Runoff from urban areas $c$ an be especially detrimental, and runoff from industrialized areas contributes greater quantities of nutrients, heavy metals, and organic contaminants to rivers than runoff from other types of urban areas, such as residential tracts (Browne and Grizzard, 1979; Wilber and Hunter, 1979a; Hunter and others, 1979).

The Saw Mill River basin is mostly urban, but land use differs from one end of the basin to the other. In the downstream section of the basin, between the City of Yonkers water-treatment plant at river mile 3.7 and the lowest sampling site at river mile $0.6,13.7$ percent of the basin is classified as manufacturing/industry/warehouse; in the remainder of the basin, upstream from the water-treatment plant, only 2.3 percent of the basin is so classified. Most of the industries in the basin are close to the river. Only 1.8 percent of the basin downstream of river mile 3.7 is undeveloped, whereas 17.1 percent of the basin upstream from that point is developed. The residential areas downstream of river mile 3.7 are medium to high density; those upstream of mile 3.7 are medium to low density. Virtually all parks, cemeteries, and other open spaces are above river mile 3.7. In accordance with this pattern, the lower part of the basin has a higher percentage of impervious area and thus a higher runoff-to-rainfall ratio than the upper part.

Orthophosphate. - The water chemistry and bottom-sediment chemistry of the Saw Mi11 River reflect the land-use distribution within the basin. The highest concentrations of dissolved orthophosphate were found at site 460 and below, the area of greatest urban development. Whipple and others (1978) reported that urbanization can markedly increase nonpoint orthophosphate loads in rivers; data summarized by Browne and Grizzard (1979) support this observation.

Heavy metals. - The heavy-metal data gathered in this study point to a deterioration in river quality in the lower part of the basin that is directly attributable to urbanization and industrialization. Typical sources and uses of heavy metals investigated in this study are listed in table 15; geologic sources are not included.

In an investigation of the relationship between heavy metals and 1 and use in a section of the Saddle River basin around the industrialized borough of Lodi, in northern New Jersey, Wilber and Hunter (1975, 1979a, 1979b) found that heavy-metal concentrations in river-bottom sediments increased with urbanization. In comparing street sweepings from industrial and residential users in Lodi, Wilber and Hunter (1979b) found that concentrations of zinc, copper, nicke 1, chromium, manganese, and iron in the industrialized area we re higher than those in the residential area and at a traffic intersection. Street sweepings are analogous to the soils analyzed in this study in that both serve as medium for the transport of heavy metals into the river, especially during times of stormwater runoff. Soils from the lower part of the Saw Mill River basin contained higher concentrations of copper, lead, and zinc than soils from the upper part of the basin, and soils subject to runoff from paved surfaces contained higher concentrations of copper, lead, and zinc than the other soils. 
The heavy-metal chemistry of the tile coatings and of the river water collected during this study strengthens the correlation between deteriorating water quality and urbanization. Tiles emplaced downstream of river mile 3.0, the most heavily developed reach of the river, contained the higher concentrations of cadmium, cobalt, copper, iron, lead, manganese, nickel, and $z$ inc than the tiles emplaced upstream. Likewise, the highest concentrations of arsenic, cadmium, copper, lead, and $z$ inc in the river water were recorded downstream of river mile 4.0 .

The heavy-metal data do not suggest a single point source of metals in the downstream reaches of the river; rather, they suggest multiple, closely spaced sources, a consequence of urban development, as the cause of the higher concentrations.

Organic compounds.--Bottom-sediment analyses for organic contaminants are more difficult to interpret than those for metals because the sorption of organic contaminants and the analytical ability to measure the contaminants are a function of the sediment composition. In addition, fewer sediment samples were analyzed for organic contaminants than for heavy metals; thus, trends in organic contaminants along the river, if present, may be difficult to detect and define at present. Some correlations between organic contaminants and land use are discernible from the data, however, as follows.

Table 15.--Uses of selected heavy metals.

\begin{tabular}{ll}
\hline Metal & \multicolumn{1}{c}{ Use or source } \\
Cadmium & $\begin{array}{l}\text { Batteries, electroplating, chemical industry, tires, } \\
\text { pigments, heating oils, motor oils, coal, plastics, } \\
\text { photography. }\end{array}$ \\
Chromium & $\begin{array}{l}\text { Alloys, refractories, electroplating, tanning industry, } \\
\text { pigments, bactericides, glass, paper mills, photography }\end{array}$ \\
Cobalt & Alloys, glass, pottery, ink, pigments, chemical industry. \\
Copper & $\begin{array}{l}\text { Electroplating, ink, dyes, pigments, alloys, tanning } \\
\text { industry, pharmaceuticals, textile industry, chemical } \\
\text { industry. }\end{array}$ \\
Lead & $\begin{array}{l}\text { Automobile exhaust, batteries, textile industry, pigments, } \\
\text { photography }\end{array}$ \\
Nickel & $\begin{array}{l}\text { Alloys, electroplating, catalyst, ceramics, storage } \\
\text { batteries, glass. }\end{array}$ \\
Zinc & $\begin{array}{l}\text { Alloys, electroplating, tanning industry, paints, tires, } \\
\text { plastics, ink, batteries, fluorescent lights, chemical } \\
\text { industry, pharmaceuticals. }\end{array}$
\end{tabular}


Bottom-sediment analyses indicate that greater amounts of PCB's are entering the river in the downstream, more industrialized, section of the basin than in the upstream section. The single water sample in which PCB's were detected came from the lowest sampling site, which supports this observation.

The greatest number of PAH's were detected in bottom sediments from the two sampling sites farthest downstream, and in general, the highest concentrations of the various compounds were at site 495. Again, the data suggest a correlation between higher contaminant concentrations and greater urban development. Daisey and others (1979) found automobile exhaust to be the greatest source of airborne PAH's in New York City; similar results were obtained in a study of PAH's in Los Angeles (Gordon, 1976). Because automobile traffic is heaviest in the lower part of the basin, the amounts of PAH's produced there is correspondingly high. Further, the high percentage of impervious area in the lower basin allows PAH aerosols that settle to land surface to be more easily washed into the river than in upstream areas of the basin, where soil cover is more extensive. Herrmann (1981) found that PAH's are adsorbed by street dust and consequently washed into urban rivers. Wakeham and others (1980) have suggested that asphalt particles that are carried into rivers by runoff are a source of $\mathrm{PAH}^{\prime} \mathrm{s}$ in heavily developed areas.

In conclusion, the orthophosphate, heavy-metal, PCB, and PAH data all indicate that the chemical quality of the Saw Mil1 River deteriorates over the lower 3 to 4 miles. Recorded discharges of these substances do not account for the deterioration. Only three permits that allow industrial discharges into the Saw Mill River have been issued by the State of New York; one allows low concentrations of oil and grease $(15 \mathrm{mg} / \mathrm{L})$ to enter the river below river mile 3.0, and the other two allow cooling water to be discharged to the river. Because the concentrations of not just one constituent but of several follow a similar trend, and because the area of highest concentrations corresponds to the area of greatest urban development, the deterioration in water quality is probably a consequence of urban runoff. In urban areas, a large percentage of contaminants attributed to nonpoint sources may actually originate from storm sewers and unrecorded point sources (Whipple and others, 1978). The occasional occurrence of untreated domestic sewage in the lowest few miles of the river indicates that unrecorded point sources are partly responsible for the deterioration in chemical quality of the lower part of the Saw Mill River.

\section{SUMMARY}

This report presents the results of a 3-year study of the chemical quality of the Saw Mill River in Westchester County. The river is $23.5 \mathrm{mi}$ long and drains a narrow $26.5-\mathrm{mi}^{2}$ basin that is primarily urban. Development is heaviest along the lower 4 miles of the river. The purpose of the study was to determine what contaminants are present in the river, determine their concentration and distribution and, if possible, determine whether the contaminants are contributed by point or nonpoint sources.

The sampling program, which extended from February 1981 through February 1983, emphasized river-bottom sediments because they sorb many types of contaminants from the water column. Water and soil samples were also taken. 
Both water and bottom-sediment samples were analyzed for heavy metals, major nutrients, and synthetic organic compounds, most of which are on the USEPA "priority pollutant" 1 ist. Several sets of ceramic tiles were emplaced in the river for study of heavy metals in the coatings that formed.

Bottom sediments were collected at 20 sites (three on tributaries), water samples at 11 sites, and soil samples at 10 sites. The ceramic tiles were emplaced and sampled at seven sites. Bottom sediments from six sites were separated into six size fractions to investigate the relationship between sediment size and the concentration of nutrients and heavy metals.

Nutrients.--Dissolved forms of organic carbon and nitrogen predominated over suspended forms in the water column. About half the phosphorus in the water column was associated with suspended sediment. None of the water samples contained nitrite, nitrate, or un-ionized ammonia in concentrations exceeding USEPA water-quality criteria or New York State Department of Health standards for sources of water supplies. Dissolved-orthophosphate concentrations were highest in the downstream third of the river. Other nutrients exhibited no trend.

Concentrations of phosphorus, organic carbon, and organic and total nitrogen in bottom sediments vary as a function of grain size. Concentrations were greater in the $1,000-$ to $2,000-\mu \mathrm{m}$ sediment than in the $250-$ to $1,000-\mu \mathrm{m}$ sediment, while the highest concentrations were in sediment fractions less than $250 \mathrm{\mu m}$. Concentrations of nitrogen, phosphorus, and organic carbon in whole bottom sediments $(<2,000 \mu \mathrm{m})$ and $1,000-$ to $2,000-\mu \mathrm{m}$ sediment were variable along the river, and no spatial trend was apparent.

Heavy metals.--Dissolved manganese was the only heavy metal to regularly exceed criteria established by the USEPA for domestic water supplies. None of the heavy metals exceeded standards for sources of water supplies established by the New York State Department of Health. Collectively, the water analyses for heavy metals indicate that water quality deteriorates downstream. The highest concentrations of copper, lead, zinc, cadmium, and arsenic were found at sites in the lowest 4 miles of the river.

Heavy-metal concentrations in sediments, like nutrient concentrations, vary as a function of grain size. Concentrations are highest in the $<63-\mu \mathrm{m}$ sediment and decrease with increasing grain size into the 500- to 1,000- $\mu \mathrm{m}$. Thereafter the concentrations again increase, giving the 1,000- to 2,000- $\mu \mathrm{m}$ sediment, the coarsest fraction analyzed, higher heavy-metal concentrations than intermediate size fractions.

Spatial variations in heavy-metal concentrations were investigated in the 1,000- to 2,000- $\mu \mathrm{m}$ sediment fraction. Bottom sediment in the lowest 3 miles of the river was found to be significantly enriched with copper, lead, and zinc. The mean concentrations of these metals in the downstream sediment were $4.0,3.8$, and 3.9 times higher, respectively, than the means for the upstream sediment. Iron and manganese exhibited no trend, nor did arsenic, cobalt, mercury, or nickel, all of which were near or less than their respective analytical detection limits. 
Heavy-metal concentrations in the soils paralleled those of the sediments. Copper, lead, and $z$ inc concentrations were highest in soils from the lower basin; iron and manganese in the soils showed no spatial trend.

Manganese was by far the most abundant metal deposited on the ceramic tiles. The concentrations of all metals investigated--cadmium, chromium, coba1t, copper, iron, lead, manganese, nickel, and zinc-were highest on tiles from the three sites downstream of river mile 3.0. The tile data form additional evidence of higher concentrations of heavy metals and, consequently, poorer water quality in the downst ream reach of the river.

Organic compounds. - -Few organic compounds were detected in water samples collected during this study. Tetrachloroethylene, 1,2-trans-dichloroethylene, trichloroethylene, and 1,1,1,-trichloroethane, all volatile compounds, were detected; concentrations ranged from 2 to $30 \mu \mathrm{g} / \mathrm{L}$. None of the compounds were found at all sites, nor did they persist at individual sites during the study. The only organochlorine compound detected in river water was PCB, which was detected in only one sample. None of the organophosphorous, acid-extractable, or base/neutral-extractable compounds on the analysis 1 ist were detected in the river water. Total phenols were found in waters at three of 11 sites sampled; the highest concentration was $4 \mathrm{\mu g} / \mathrm{L}$ at river mile 1.5 .

Chlordane, DDD, DDE, DDT, dieldrin, and PCB's were found in bottom sediments along the entire river. The six highest PCB concentrations occurred in the lowest 6 miles of the river. None of the other compounds exhibited spatial trends. Of the 57 acid- and base/neutral-extractable compounds on the USEPA "priority pollutant" list, 22 were detected in bottom sediments. None was found at all sampling sites. Of the 22 compounds, 16 were polynuclear aromatic hydrocarbons, and four were phthalate esters. The greatest variety of compounds found was at the two lowermost sites, downstream of river mile 2.0 .

General trends.--Urban development is greatest in the lowest part of the Saw Mil1 River drainage basin, which is within the City of Yonkers. The percentage of land downstream from the City of Yonkers water-treatment plant that is used by industry is about six times greater than the percentage of land so used upstream from the plant, which is 3.7 miles from the river mouth.

The distributions of orthophosphate, heavy metals, PCB's, and polynuclear aromatic hydrocarbons all indicate that the chemical quality of the Saw Mill River deteriorates downstream over the lowest 4 river miles. The coincidence of the higher concentrations of a variety of contaminants within the area of greatest urban development indicates urban runoff to be the major cause of the downstream deterioration in river quality. 


\section{REFERENCES}

Archer, R. J., and Turk, J. T., 1977, Discharge and water-quality data for selected streams at low flow including some bottom-material analyses, and 1 imnological study of six lakes, Westchester County, New York: U.S. Geological Survey Open-File Report 77-781, 72 p.

Beetem, W. A., Perryman, G. R., Anthony, E. R., and Friedman, L. C., eds., 1981, 1982 Water Quality Laboratory Services Catalog: U.S. Geological Survey Open-File Report 81-1016, p. 2-31 to 2-54 and 3-13 to 3-18.

Browne, F. X. and Grizzard, T. J., 1979, Water pollution-nonpoint sources: Journal of the Water Pollution Control Federation, v. 51, p. 1428-1444.

Carpenter, R. H., and Hayes, W. B., 1978, Precipitation of iron, manganese, zinc, and copper on clean, ceramic surfaces in a stream draining a polymetallic sulfide deposit: Journal of Geochemical Exploration, v. 9, p. 31-37.

, 1980, Annual accretion of Fe-Mn oxides and certain associated metals in a stream environment: Chemical Geology, v. 29, p. 249-259.

Carpenter, R. H., Pope, T. A., and Smith, R. L., 1975, Fe-Mn oxide coatings in stream sediment geochemical surveys: Journal of Geochemical Exploration, v. 4, p. 349-363.

Cerling, T. E., and Turner, R. R., 1982, Fgrmation of freshwater Fe-Mn coatings on gravel and the behavior of ${ }^{6} \mathrm{Co},{ }^{9} \mathrm{Sr}$, and ${ }^{137} \mathrm{Cs}$ in a small watershed: Geochimica et Cosmochimica Acta, v. 46, no. 8, p. 1333-1343

Cressey, G. B., 1966; Land forms, in Thompson, J. H., ed., Geography of New York State: Syracuse, N. Y., Syracuse University Press, p. 19-53.

Daisey, J. M., Leyko, M. A., and Kneip, T. J., 1979, Source identification and allocation of polynuclear aromatic hydrocarbon compounds in the New York City aeroso1--methods and applications, in Jones, P. W. and Leber, Philip, eds., Polynuclear aromatic hydrocarbons: Ann Arbor, Mich., Ann Arbor Science, p. 201-215.

Davies, B. E., 1980, Trace element pollution, in Davies, B. E., ed., Applied soil trace elements: New York, John Wiley, p. 287-351.

Feltz, H. R., 1980, Significance of bottom material data in evaluating water quality, in Baker, R. A., ed., Contaminants and sediments (vol. 1): Ann Arbor, Mich., Ann Arbor Science Publishers, p. 271-287.

Fisher, D. W., Is achsen, Y. W., and Richard, L. V., 1970, Geologic map of New York, lower Huds on sheet: New York State Museum and Science Service, Map and Chart Series No. 15., scale 1:250,000.

Fishman, M. J., and Bradford, W. L., eds., 1982, A supplement to methods for the determination of inorganic substances in water and fluvial sediments: U.S. Geological Survey Techniques of Water-Resources Investigations, book 5, chap. Al, U.S. Geological Survey Open-File Report 82-272, 136 p. 


\section{REFERENCES (contInued)}

Goerlitz, D. F., and Brown, Eugene, 1972, Metnods for analys is of organic substances in water: U.S. Geological Survey Techniques of Water-Resources Investigations, book 5, chap. A3, 40 p.

Goerlitz, D. F., and Law, L. M., 1974, Distribution of chlorinated hydrocarbons in stream-bottom material: U.S. Geological Survey, Journal of Research, v. 2 , no. 5, p. 541-543.

Gordon, R. J., 1976, Distribution of airborne polycyclic aromatic hydrocarbons throughout Los Angeles: Environmental Science and Technology, v. 10, no. 4, p. 376-373.

Herrmann, Reimer, 1981, Transport of polycyclic aromatic hydrocarbons through a partly urbanized river basin: Water, Air, and Soil Pollution, v. 16, p. 445-467.

Hunter, J. V., Sabatino, T., Gomputs, R., and Mackenzie, M. J., 1979, Contribution of urban runoff to hydrocarbon pollution: Journal of the Water Pollution Control Federation, v. 51, no. 8, p. 2129-2138.

Keith, L. H., and Telliard, W. A., 1979, Priority pollutants I--a perspective view: Environmental Science and Technology, v. 13, no. 4, p. 416-423.

Laube, V., Ramamoorthy, S., and Kushner, D. J., 1979, Mobilization and accumulation of sediment bound heavy metals by algae: Bulletin of Environmental Contamination and Toxicology, v. 21, p. 763-770.

Lopez-Avila, Viorica, and Hites, R. A., 1980, Organic compounds in wastewater-their transport into sediments: Environmental Science and Technology, v. 14, no. 11 , p. 1382-1390.

Mackenthun, K. A., 1973, Toward a cleaner aquatic environment: U.S. Environmental Protection Agency, 273 p.

Me ans, J. C., Wood, S. G., Hassett, J. J., and Banwart, W. L., 1980, Sorption of polynuclear aromatic hydrocarbons by sediments and soils: Environmental Science and Technology, v. 14, no. 12, p. 1524-1528.

New York State Department of Environmental Conservation, 1974-, C1assification and standards governing the quality and purity of water of New York St ate: Parts 700-703, Title 6, Official Compilation of Codes, Rules, and Regulations of the State of New York.

New York State Department of Health, 1977, Drinking water supplies standards: Part 5, Subpart 5-1, Chapter I, Title 10 (Health) of the Official Compilation of Codes, Rules, and Regulations of the State of New York.

Qasim, S. R., Armstrong, A. T., Corn, J., and Jordan, B. L., 1980, Quality of water and bottom sediments in the Trinity River: Water Resources Bulletin, v. 16, no. 3, p. 522-531. 


\section{REFERENCES (continued)}

Rickert, D. A., Kennedy, V. C., McKenzie, S. W., and Hines, W. G., 1977, A synoptic survey of trace metals in bottom sediments of the Willamette River, Oregon: U.S. Geological Survey Circular 715-F, 27 p.

Skougstard, M. W., Fishman, M. J., Friedman, L. C., Erdmann, D. E., and Duncan, S. S., eds., 1979, Methods of determination of inorganic substances in water and fluvial sediment: U.S. Geological Survey Techniques of Water-Resources Investigations, book 5, chap. Al, 626 p.

U.S. Army Corps of Engineers, 1979, Local flood protection reformulation documentation $\mathrm{Ph}$ ase I, Advanced engineering and design, Saw Mill River at Elms ford and Greenburgh, New York, Appendix A--Hydrology: New York, U.S. Army Corps of Engineers, 1 v.

U.S. Environmental Protection Agency, 1977, Quality criteria for water: Washington, D.C., 256 p.

, 1979a, EPA method 624-Purgeables: Federal Register, v. 44, no. 233, p. 69532-69539.

, 1979b, EPA method 625--base/neutrals, acids, and pesticides: Federal Register, v. 44, no. 233, p. 69540-69522.

Wakeham, S. G., Schaffner, Christian, and Giger, Walter, 1980, Polycyclic aromatic hydrocarbons in recent 1 ake sediments $I$. Compounds having anthropogenic origins: Geochimica et Cosmochimica Acta, v. 44, no. 3, p. 403-413.

Westchester County, 1978, Areawide waste treatment management plan: Westchester County, N.Y., Water Quality Planning Task Force, 1 v.

Whipple, W., Berger, B. B., Gates, C. D., Ragan, R. M., and Randa11, C. W., 1978, Characterization of urban runoff: Water Resources Research, v. 14 , no. 2 , p. 370-372.

Whitney, P. H., 1975, Relationship of manganese-iron oxides and associated heavy metals to grain size in stream sediments: Journal of Geochemical Exploration, v. 4, p. 251-263.

Wilber, W. G., and Hunter, J. V., 1975, Contributions of metals resulting from storm-water runoff and precipitation in Lodi, New Jersey, in Whipple, W., G., ed., Urbanization and water quality control: Minneapolis, Minn., American Water Resources Association, p. 44-55.

, 1979a, The impact of urbanization on the distribution of heavy metals in bottom sediments of the Saddle River: Water Resources Bulletin, v. 15, no. 3, p. 790-800.

, 1979b, Distribution of metals in street sweepings, storm-water solids, and urban aquatic sediments: Journal of the Water Pollution Control Federation, v. 51, no. 12, p. 2810-2822. 
TABLES $16,17,18$

Page

Table 16.--Concentrations of nitrogen, phosphorus, and carbon in water from the saw Milz River, 1981-82.

Table 17.--Concentrations of nitrogen, phosphorus, and carbon in bottom sediments from the Saw Milz River, 1981-82.

Table 18.--Concentrations of heavy metals in waters from the Saw Mill River, 1981-82. 


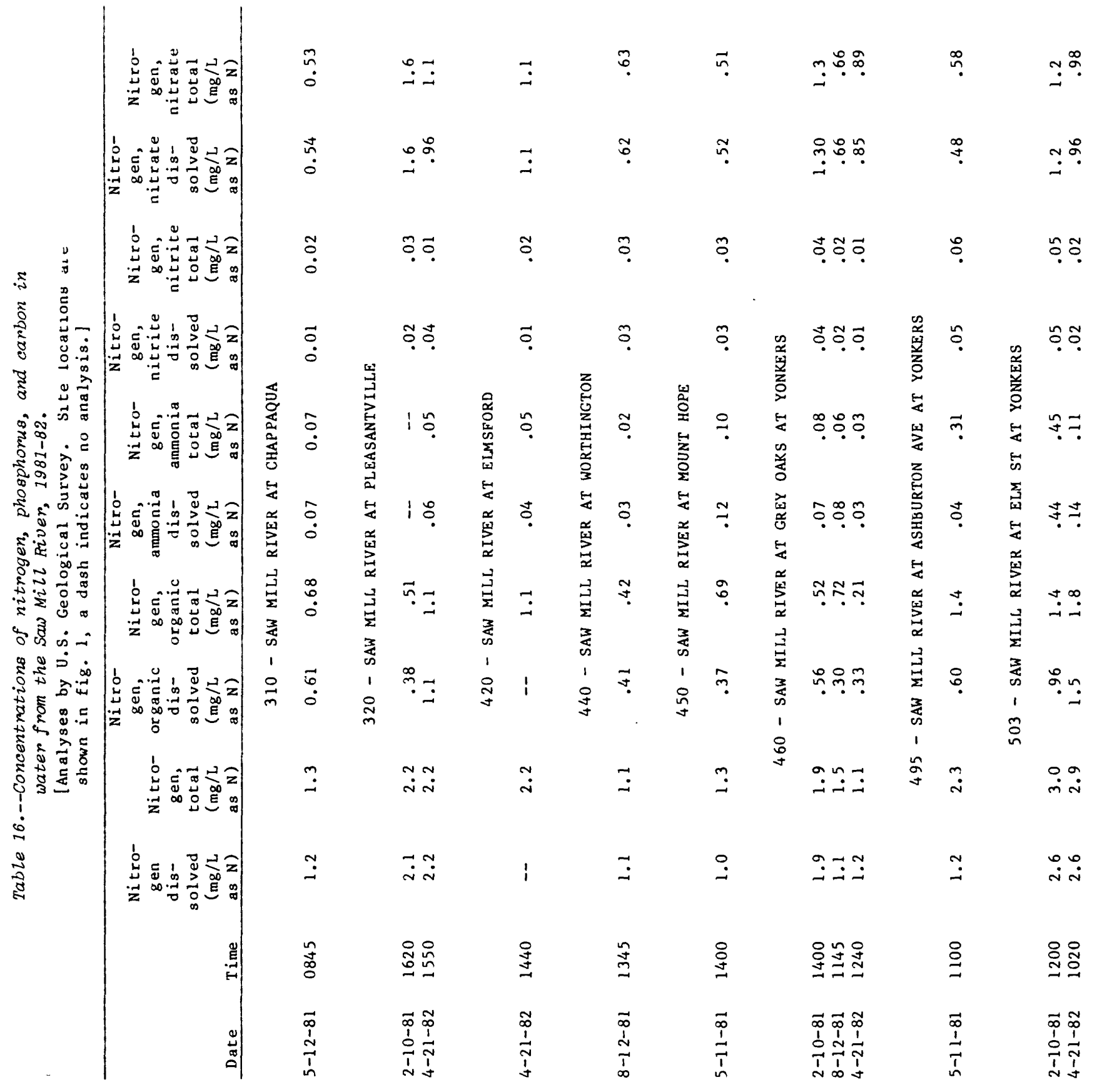









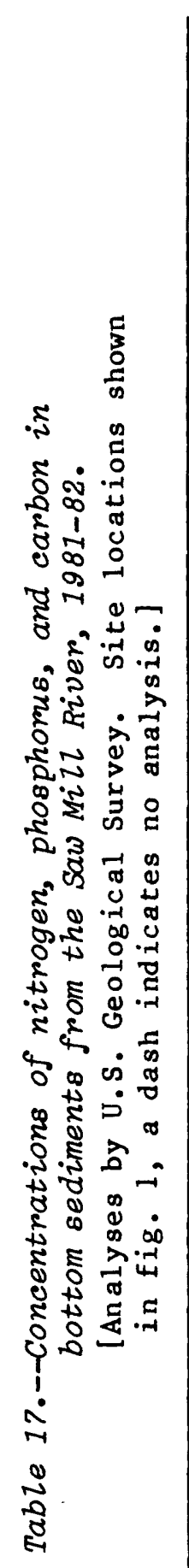

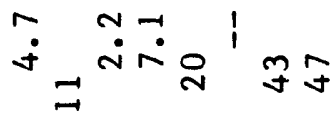

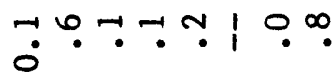

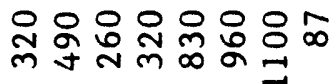

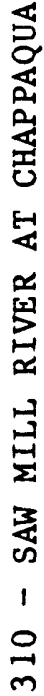

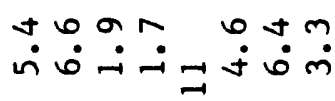

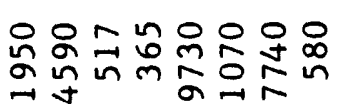
$\stackrel{1}{m}$

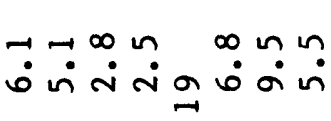
0
0
0 응 8

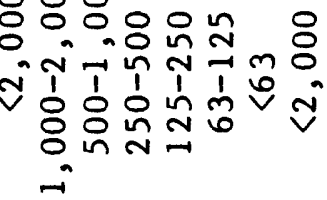

$\vec{\infty} \vec{\infty} \vec{\infty} \vec{\infty} \vec{\infty} \vec{\infty} \vec{\infty} \vec{\infty}$ ง ที่ $\begin{array}{llll}m & 0 & 0 \\ 0 & 0 & + & 0\end{array}$

ㅇำ



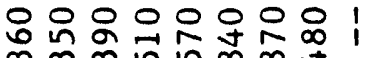

응

at $t 0$

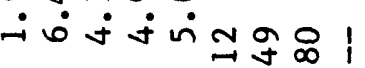

ڤె

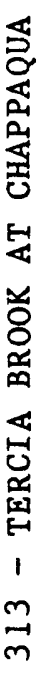

N

4

焉

o

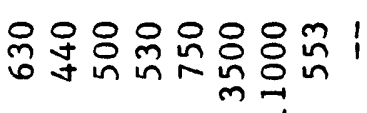

$m \beth$

흔



$\stackrel{N}{N}$

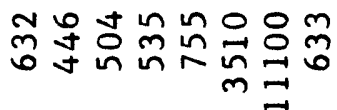

ํำ

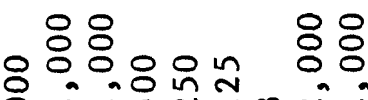

ำ
ํ.

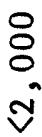
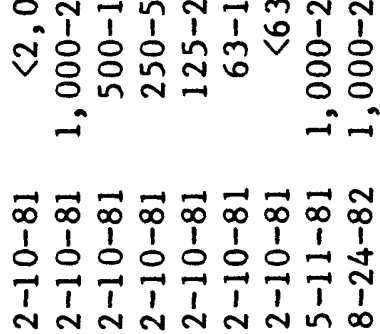







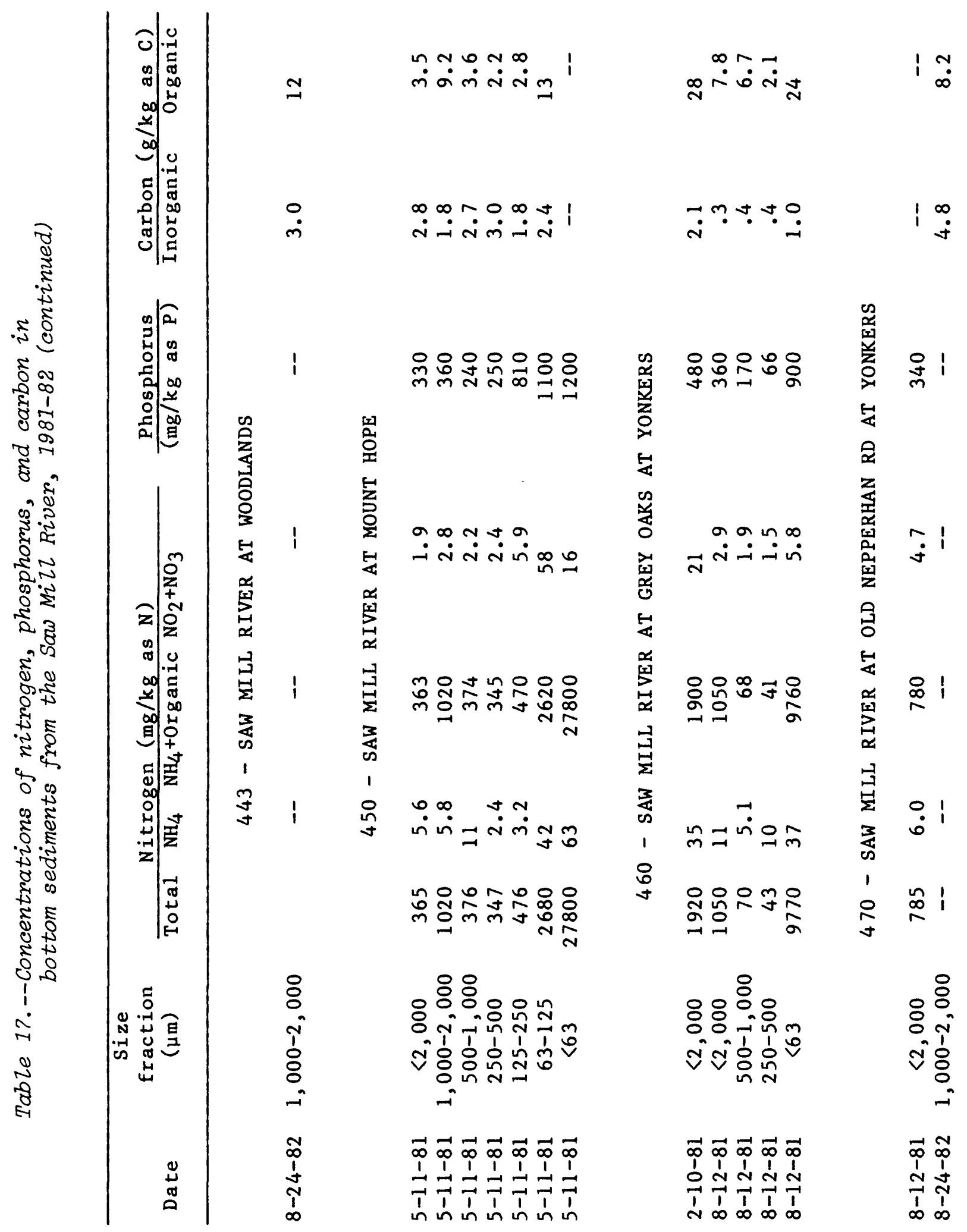



$\simeq 1$

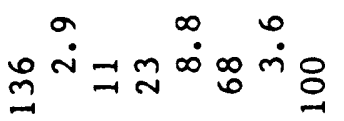

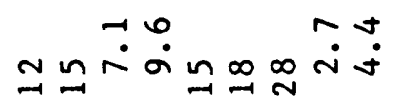

$\stackrel{+}{j}$

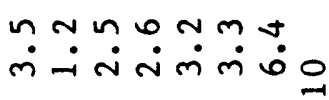

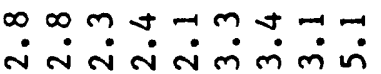

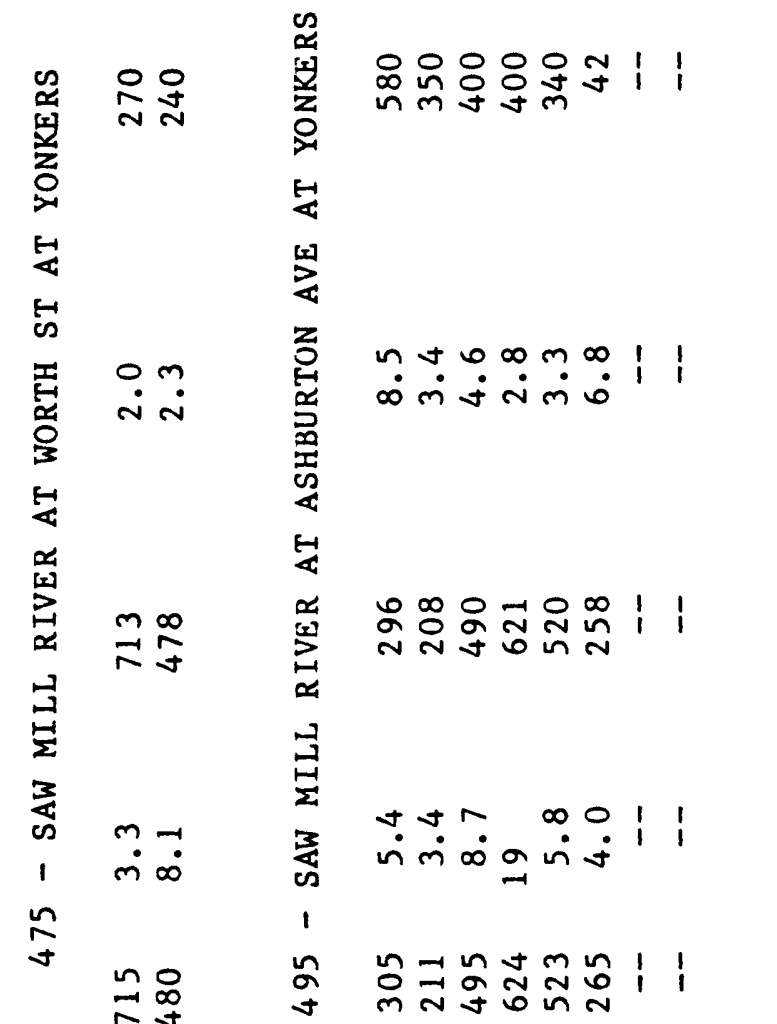

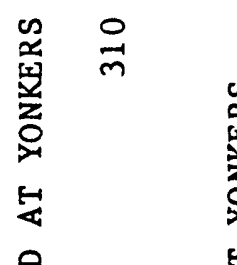



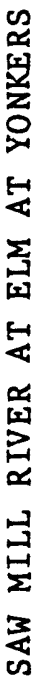

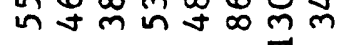

2

秥

贸

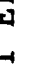

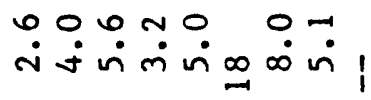

采

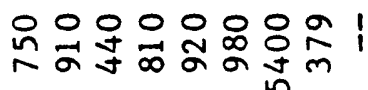

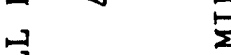

in

年

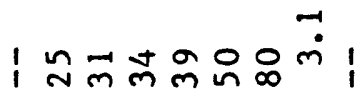

ờ

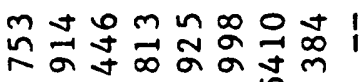

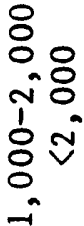

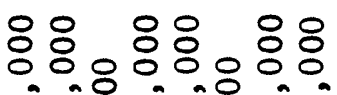
n-ioninninn

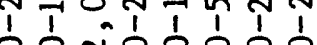

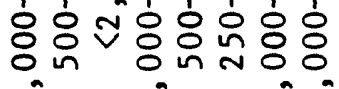

i

융요 융 on

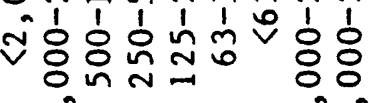
品

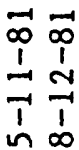



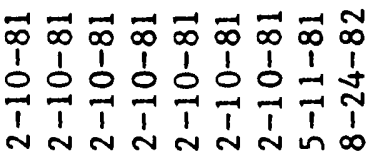




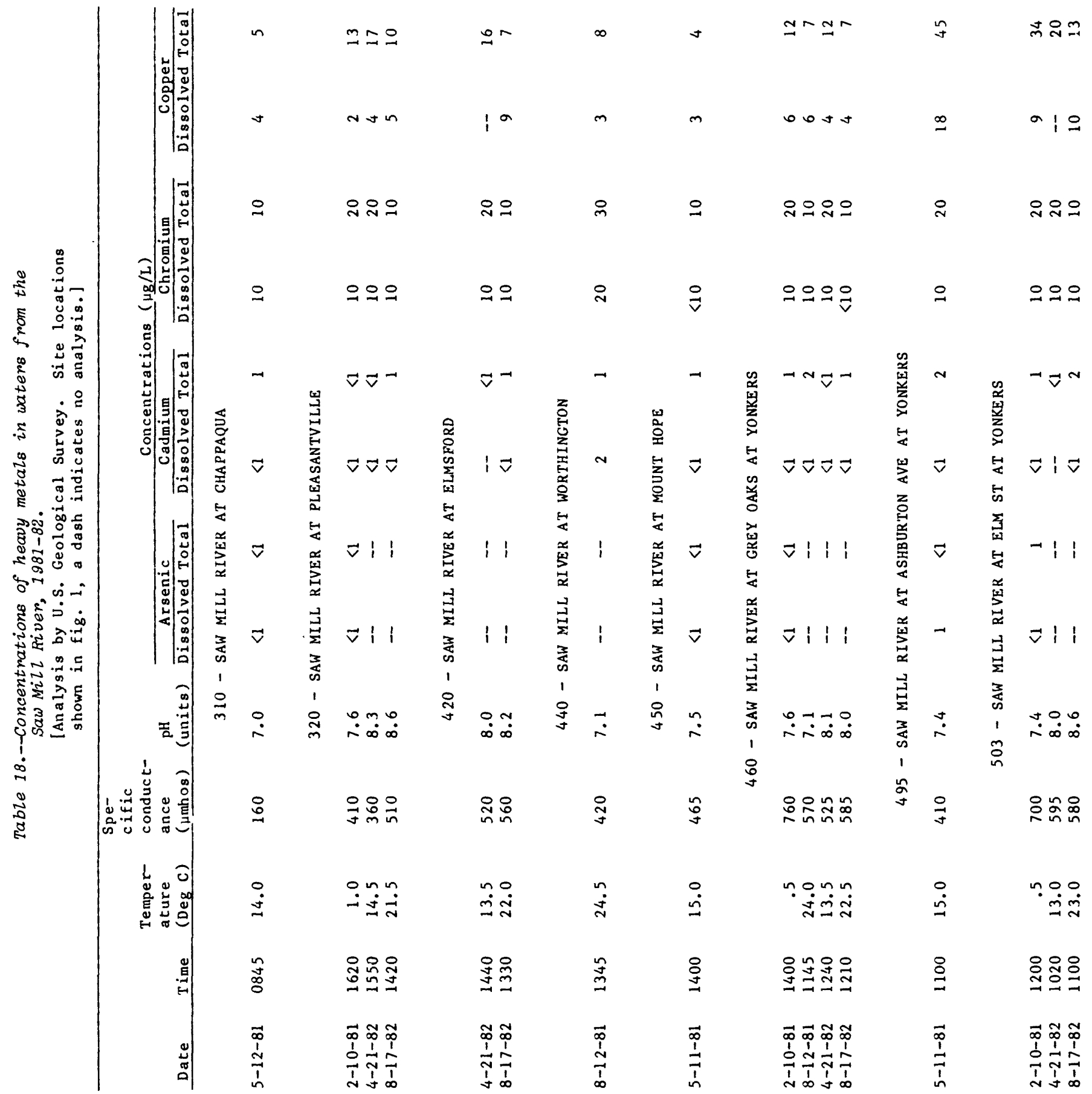




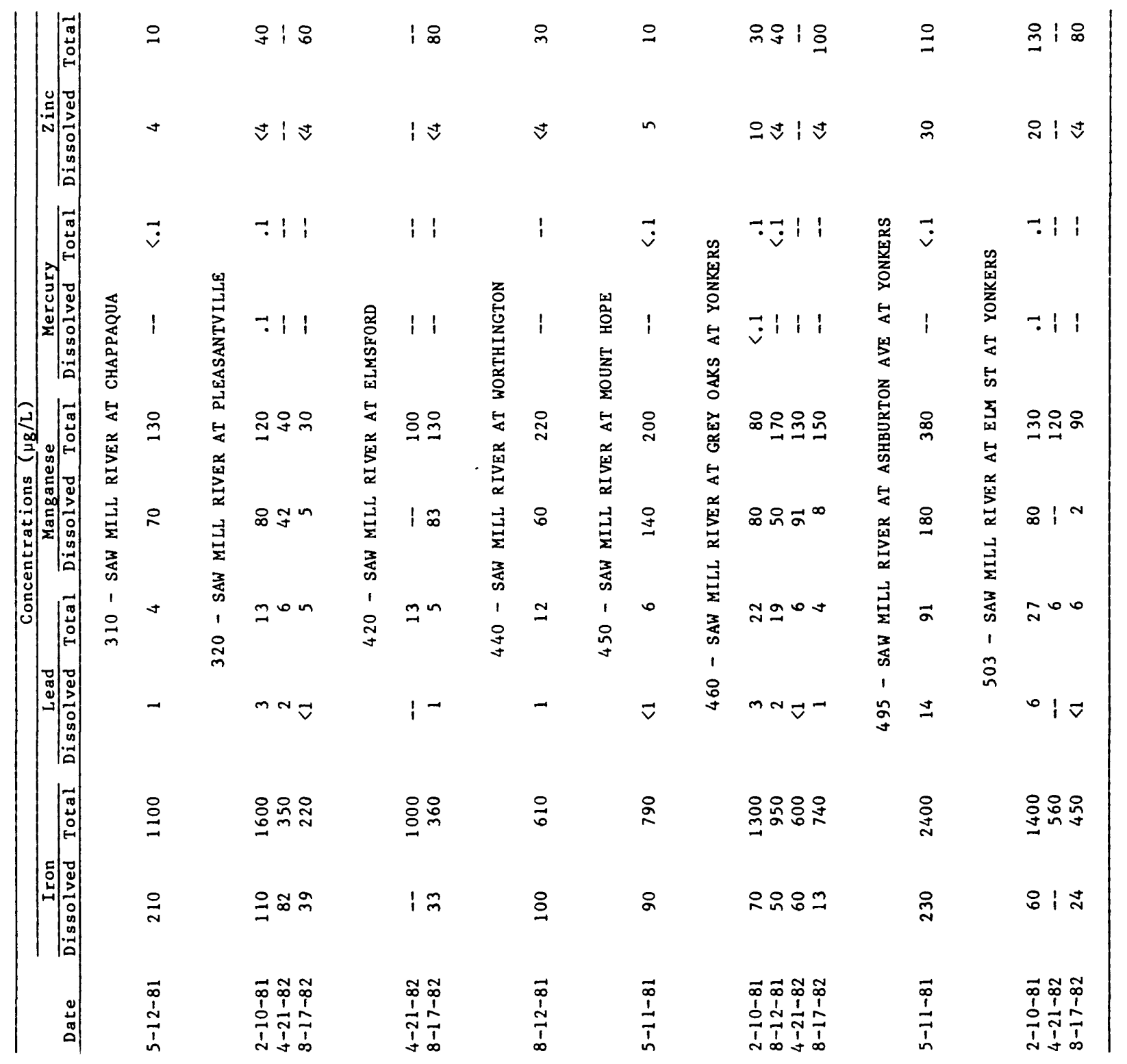

